\title{
BADANIA DOSTĘPNOŚCI PUBLICZNEGO TRANSPORTU ZBIOROWEGO W PODREGIONIE PILSKIM
}

\section{Research on the availability of public transport in the Piła subregion \\ Michał Beim (1), Angelika Błażeczek (2), Agnieszka Dąbrowska (3), Paulina Dębiak (4), Anna Olczyk (5)}

(1) Pracownia Gospodarki Przestrzennej i Geodezji, Wydział Inżynierii Środowiska i Gospodarki Przestrzennej, Uniwersytet Przyrodniczy w Poznaniu, Piątkowska 94, 60-649 Poznań

e-mail: michal.beim@up.poznan.pl

(2) Pracownia Gospodarki Przestrzennej i Geodezji, Wydział Inżynierii Środowiska i Gospodarki Przestrzennej, Uniwersytet Przyrodniczy w Poznaniu, Piątkowska 94, 60-649 Poznań

e-mail: b.angelika.blazeczek@gmail.com

(3) Pracownia Gospodarki Przestrzennej i Geodezji, Wydział Inżynierii Środowiska i Gospodarki Przestrzennej, Uniwersytet Przyrodniczy w Poznaniu Piątkowska 94, 60-649 Poznań

e-mail: a.dabrowska94@wp.pl

(4) Pracownia Gospodarki Przestrzennej i Geodezji, Wydział Inżynierii Środowiska i Gospodarki Przestrzennej, Uniwersytet Przyrodniczy w Poznaniu, Piątkowska 94, 60-649 Poznań

e-mail: puullii9620@gmail.com

(5) Pracownia Gospodarki Przestrzennej i Geodezji, Wydział Inżynierii Środowiska i Gospodarki Przestrzennej, Uniwersytet Przyrodniczy w Poznaniu, Piątkowska 94, 60-649 Poznań

e-mail: anna.olczyk.94@gmail.com

Cytacja:

Beim M., Błażeczek A., Dąbrowska A., Dębiak P., Olczyk A., 2019, Badania dostępności publicznego transportu zbiorowego w podregionie pilskim, Prace Komisji Geografii Komunikacji Polskiego Towarzystwa Geograficznego, 22(4), 95-118.

Streszczenie: Głównym celem artykułu jest określenie poziomu dostępności publicznym transportem zbiorowym w podregionie pilskim. Badania zostały wykonane z perspektywy pasażerskiej w ramach analizy publicznie dostępnych informacji o rozkładach jazdy. Analizy dokonano w podziale na miejscowości według bazy PRNG, dzięki czemu możliwe było szczegółowe określenie miejscowości i odsetka osób posiadających określony poziom usług lub pozbawionych w ogóle możliwości dojazdów transportem publicznym. Przebadane zostały również kwestie taryfowe ofert, a także dostępność do informacji o usługach. Wyniki badań pokazują, iż w dni nauki szkolnej w podregionie pozbawionych połączeń autobusowych jest $22 \%$ mieszkańców. Problem radykalnie wzrasta w dni robocze w okresie ferii szkolnych (44\%) oraz w soboty (60\%) i niedziele (63\%). Inaczej prezentuje się dostępność kolei. Wprawdzie ponad połowa mieszkańców regionu nie ma dostępu do jej usług, jednak oferta jest bardziej atrakcyjna pod względem stabilności rozkładów jazdy we wszystkie dni roku, a także systemu taryfowego. Zaletę kolei stanowi również dobry dostęp do informacji o rozkładzie.

Słowa kluczowe: dostępność, transport publiczny, transport regionalny

Abstract: The main purpose of the paper is to examine the accessibility level of public transport in the Piła subregion. The research was conducted from a passenger perspective - by analyzing publicly available information about timetables. The studies were conducted for each village or town in the database of the State Register of Geographical Names. Thanks this approach was possible to describe a certain level of services for each settlement and calculate the percentage of people not having any access to public transport. Tariff issues regarding offers as well as availability of information on services were also analyzed. Research results show that on school days there are $22 \%$ of residents in the subregion without bus or rail connections. The problem, however, increases dramatically on business days during school holidays $(44 \%)$ and on Saturdays $(60 \%)$ and Sundays (63\%). The issue of rail accessibility is different. Although more than half of the region's inhabitants do not have access to services, the offer is more attractive in terms of timetable stability on all days of the year, as well as the tariff system. The advantage of rail is also good access to information about the timetable.

Keywords: accessibility, public transport, regional transport 


\section{Wstęp}

Niniejsze badania przypadają na czas, w którym analiza publicznego transportu zbiorowego poza aglomeracjami miejskimi wyszła poza akademicką dyskusję. Nie zachęciło to organizatorów przewozów do dokonania radykalnych zmian w przyjętych planach transportowych gmin, powiatów czy województw lub do ogłaszania zamówień publicznych na świadczenie usług przewozowych. Debata publiczna pobudziła jednak znacząco politykę na szczeblu krajowym. Efektem były liczne deklaracje polityczne na rzecz rozwoju transportu regionalnego, a w konsekwencji uchwalenie ustawy z dnia 16 maja 2019 r. o Funduszu rozwoju przewozów autobusowych o charakterze użyteczności publicznej (Dz.U. 2019 poz. 1123), do której wydane zostało rozporządzenie Rady Ministrów z dnia 26 lipca 2019 r. w sprawie szczegółowego sposobu podziału środków Funduszu rozwoju przewozów autobusowych o charakterze użyteczności publicznej na dofinansowanie realizacji zadań własnych organizatorów w zakresie przewozów autobusowych o charakterze użyteczności publicznej w poszczególnych województwach (Dz.U. 2019 poz. 1406).

Polska nie jest jedynym krajem Europy, w którym dyskusja akademicka i debata polityczna o wykluczeniu transportowym przenikają się i owocują rządowymi programami. J. Preston i F. Rajé (2007) omawiają podobne działania podejmowane w Wielkiej Brytanii. Już trzy dekady wcześniej M.J. Moseley (1979) wskazywał na wyzwanie w obsłudze transportowej, jakie stwarzają obszary poza aglomeracjami. Wiele z poruszanych problemów jest zbliżonych do rzeczywistości transportowej polskiej prowincji: uzależnienie jej mieszkańców od indywidualnej motoryzacji, a $w$ przeciwnym razie utrudnienia w dostępie do edukacji, opieki zdrowotnej czy lepiej płatnej pracy. Dzieje się tak na skutek decyzji politycznych, związanych przede wszystkim z likwidacją linii kolejowych dokonaną dekadę wcześniej. S. Gibbons i in. (2018) stawiają wręcz tezę, iż "siekiera Beechinga”, jak potocznie nazwano likwidacje linii kolejowych sprzed pół wieku, mają nadal negatywne skutki dla rozwoju społeczno-ekonomicznego brytyjskiej prowincji.

Niniejsza praca nie podejmuje jednak problematyki uwarunkowań prawnych regionalnego publicznego transportu zbiorowego w podregionie pilskim, zarówno na poziomie krajowym (umocowania ustawowe), jak i regionalnym czy lokalnym (plany transportowe, uwarunkowania finansowe). Nie porusza także społecznych i ekonomicznych konsekwencji wykluczenia. Celem badań było jedynie szczegółowe określenie poziomu dostępności transportu publicznego, rozumianego jako liczba kursów oferowana w danej miejscowości. Badania te w przyszłości mogą posłużyć do oceny efektywności nowych przepisów oraz oceny zmian w systemie transportowym podregionu. Wybór podregionu pilskiego wynikał z kilku przyczyn. Składał się na nie zróżnicowany układ przestrzenny - od terenów z dominacją obszarów leśnych na północy i zachodzie, przez tereny zurbanizowane w centrum, po tereny z dominacją obszarów rolniczych na południu i zachodzie - oraz mniejsza zamożność i niższe uprzemysłowienie niż w pozostałej części województwa wielkopolskiego. Podregion pilski doświadczył w okresie transformacji likwidacji linii kolejowych, a równocześnie przez jego obszar przebiega kilka istotnych w skali kraju korytarzy transportowych. Umożliwia to pewną generalizację wniosków.

\section{Stan badań nad transportem na obszarach niezurbanizowanych w Polsce}

Funkcjonowanie transportu publicznego poza obszarami miejskimi jest zagadnieniem bardzo złożonym. Zbiorczo charakterystykę ośrodków naukowych prowadzących badania w tym zakresie przedstawiają P. Rosik i in. (2018). Zasadnicza różnica prowadzonych analiz polega jednak na ich perspektywie: od kwestii przekrojowych i porównawczych dla całego obszaru kraju, po szczegółowe badania podaży i popytu transportowego w skali lokalnej czy ponadlokalnej. Każdy system transportowy może być ponadto badany w podziale branżowym, tj. w kontekście historycznym, społecznym, politycznym, środowiskowym czy ekonomicznym. Również sama dostępność transportu publicznego determinowana jest przez kilka wymiarów, m.in. czasowy, ekonomiczny, administracyjny, przestrzenny, informacyjny czy techniczny (por. Gadziński, Beim, 2009). Fakt zaistnienia oferty transportu publicznego należy rozpatrywać w szerokim kontekście uwarunkowań przestrzennych (por. Banister, 2001), jak i wpływu na rozwój regionalny danego obszaru (por. Taylor, 1999; Beim, 2014).

W niniejszej publikacji zaproponowano pewien podział prac związanych z badaniami dotyczącymi dostępności transportu publicznego, uzależniając go od kompleksowości i szczegółowości badań (ryc. 1). W pierwszej grupie zaproponowano podstawowe analizy dostępności oferty transportu publicznego, posiadające przede wszystkim walor porównawczy. W drugiej grupie zamieszczono rozszerzoną analizę dostępności, na którą składa się nie tylko występowanie oferty czy jej charakterystyka czasowa (godziny odjazdów), przestrzenna (kierunki połączeń), ale również jakościowa (np. dostępność taboru dla osób z ograniczoną mobilnością, dostępność do informacji o połączeniach) oraz ekonomiczna (np. system tary- 
fowy). Trzecia grupa dotyczy analiz lokalnych uwarunkowań dostępności, takich jak drogi dojścia do przystanków, wydłużenie trasy czy straty czasu z tym związane. Ostatnią grupę stanowią szczegółowe analizy wpływu dostępności transportem publicznym na rozwój społeczno-gospodarczy. W ostatniej dekadzie obserwuje się intensywny rozwój polskich badań nad dostępnością publicznego transportu zbiorowego. Wyjątek stanowi jedynie trzecia grupa, reprezentowana na razie przez nieliczne prace (np. Sior, 2013; Sołtysiak, 2014; Malasek, 2017).

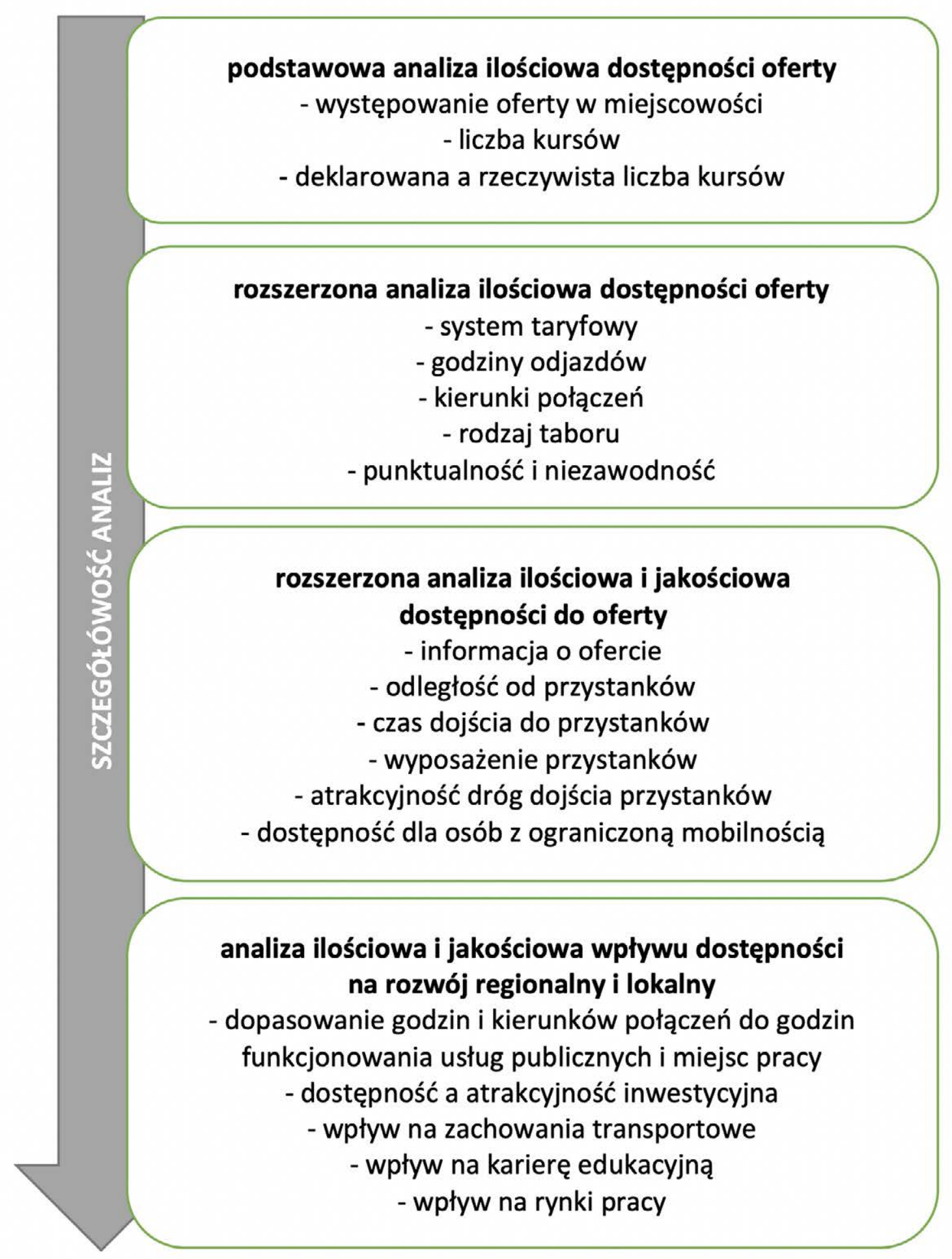

Ryc. 1. Przegląd koncepcji badań nad dostępnością transportu publicznego. 


\section{Metodyka badań}

Celem badań było określenie poziomu dostępności transportowej w wymiarze przestrzennym, ekonomicznym i informacyjnym na obszarze podregionu pilskiego, z uwzględnieniem podziału na miejscowości. Lokalizację i nazwy miejscowości pobrano z Państwowego Rejestru Nazw Geograficznych (PRNG), z podzbioru miejscowości. Zbioru miejscowości nie należy utożsamiać z podziałem administracyjnym na sołectwa, gdyż może ono obejmować jedną wieś, przysiółek czy osadę, tylko część miejscowości (w miejscowości jest kilka sołectw) lub kilka miejscowości. W toku przygotowań do badań - analiz map topograficznych - uznano bowiem, iż podział na sołectwa nie odzwierciedla do końca struktury osadniczej, a oddalenie miejscowości w ramach tego samego sołectwa może wynosić kilka kilometrów, co ma niebagatelne znaczenie $w$ analizach dostępności transportu publicznego (np. Osuch i Romanowo Dolne w gminie wiejskiej Czarnków, 2,8 km odległości). Ponadto zdarza się ulokowanie wsi sołeckiej poza głównym szlakiem komunikacyjnym przy jednoczesnym występowaniu przystanków autobusowych w innych wsiach leżących na szlaku komunikacyjnym, na obrzeżach sołectwa (np. Pomarzanki w gminie Skoki).

Zastosowanie w analizie wykazu miejscowości z zasobu PRNG umożliwiło również zestawienie wyników z liczbą mieszkańców. Wprawdzie najnowsze informacje o liczbie ludności pochodzą z Narodowego Spisu Powszechnego z 2011 r., niemniej stanowią one najbardziej dokładną, publicznie dostępną informację, pozwalającą w najbardziej szczegółowy sposób określić liczbę osób pozbawionych jakiegokolwiek dostępu do publicznego transportu zbiorowego.

Zespół badawczy przyjął pewne uproszczenie odnośnie do lokalizacji przystanków względem struktury osadniczej. Za zaistnienie oferty transportu publicznego uważano funkcjonowanie przynajmniej jednego przystanku posiadającego w swej nazwie nazwę miejscowości. W rzeczywistości zdarzały się takie sytuacje, iż przystanek autobusowy czy kolejowy był znacząco oddalony od skupiska zabudowy, wymuszając dojście piesze ponad kwadrans i to zazwyczaj w warunkach nieprzyjaznych pieszym, tj. bez oświetlonych chodników. W świetle badań (Otsuka i in., 2019) może to mieć realne, negatywne przełożenie nie tylko na atrakcyjność transportu publicznego, ale na samą dostępność w przypadku ograniczeń mobilności niektórych potencjalnych pasażerów.

W pracy przyjęto definicję operacyjną transportu regionalnego jako połączenia pomiędzy dwiema dowolnymi miejscowościami podregionu pilskiego przekraczające przynajmniej jedną granicę gminy.
W definicji tej mieściły się zarówno kursy komunikacji miejskiej do sąsiedniej gminy, jak i kursy pociągów lub autobusów dalekobieżnych zatrzymujące się choćby dwa razy na analizowanym obszarze.

Założono, iż punktem wyjściowym badań jest perspektywa potencjalnego pasażera, który chce odbyć podróż do danej miejscowości i na zdobycie informacji w źródłach internetowych nie zamierza poświęcić więcej czasu niż kilka minut. Jest to zasadnicza różnica w stosunku do innych badań bazujących na decyzjach administracyjnych (np. Rosik i in., 2018) lub deklaracjach sołtysów (np. Stanny i in., 2018) albo deklaracjach ankietowanych osób (np. Wolański i in., 2016). Źródłami danych o rozkładach były informacje udostępniane przez przewoźników, organizatorów lub operatorów publicznego transportu zbiorowego, internetowe wyszukiwarki połączeń, internetowe rozkłady jazdy dla poszczególnych przystanków oraz informacje na stronach gmin lub powiatów, a także rozkłady jazdy publikowane przez PKP Polskie Linie Kolejowe oraz Wyrzyską Kolej Powiatową. Przyjęcie takiej perspektywy stanowiło novum w badaniach nad transportem regionalnym. Założono bowiem, iż dostęp do informacji o ofercie jest czynnikiem wpływającym na samą ofertę transportu publicznego. Przedmiotem analiz nie były więc wykazy decyzji administracyjnych - zezwoleń lub zaświadczeń o statusie operatora.

Badania uwzględniały również kwestię uwarunkowań taryfowych oraz dostępu do informacji pasażerskiej oferowanej przez przewoźników lub organizatorów publicznego transportu zbiorowego w podregionie pilskim. Okresem prowadzenia badań był pierwszy tydzień czerwca 2019 r. - analizie poddano obowiązujące wówczas rozkłady jazdy.

\section{Obszar badań}

Badania dostępności transportu publicznego zostały wykonane na terenie podregionu pilskiego, delimitowanego zgodnie z podziałem NUTS 3, w skład którego wchodzą powiaty chodzieski, czarnkowsko-trzcianecki, pilski, wągrowiecki, złotowski. W podregionie znajduje się łącznie 37 gmin, w tym pięć miejskich i 14 miejsko-wiejskich. Należy nadmienić, że specyfiką podregionu jest istnienie gmin wiejskich o tej samej nazwie, co gmina miejska z największym ośrodkiem $w$ danym powiecie (poza powiatem pilskim), stanowiących tzw. obwarzanek. Fakt ten jest o tyle istotny, że gminy wiejskie często lokują na terenie miasta również inne usługi niż tylko urząd gminy. Przejazd przez granicę gminy stanowi zawsze wyzwanie administracyjne przy organizacji publicznego transportu zbiorowego.

Podregion pilski w porównaniu z resztą województwa wielkopolskiego cechuje się mniej ko- 
rzystnymi parametrami rozwoju społeczno-ekonomicznego. W momencie prowadzenia badań, tj. w czerwcu 2019 r., wszystkie powiaty charakteryzowały się zdecydowanie wyższym poziomem stopy bezrobocia niż średnia wojewódzka wynosząca 2,8\%, tj. od 3,8\% w powiecie czarnkowsko-trzcianeckim do $6,2 \%$ w powiecie chodzieskim. Ponadto wszystkie powiaty posiadały znacząco niższą gęstość zaludnienia niż średnia województwa wielkopolskiego. Fakty te wpływają niekorzystnie na rozwój publicznego transportu zbiorowego.

Czynnikiem pozytywnie kształtującym rozwój oferty przewozowej jest wyższa niż przeciętnie w województwie liczba dzieci i młodzieży w wieku szkolnym, stanowiących zazwyczaj podstawę wśród klientów regionalnego transportu autobusowego. Istotny jest także niższy poziom motoryzacji. Pod względem liczby samochodów osobowych tylko powiat chodzieski i wągrowiecki mają wyższy wskaźnik niż średnia wojewódzka (tab. 1). więc czynnika wpływającego na atrakcyjność indywidualnej motoryzacji ani budującego przewagę nad transportem publicznym.

Podregion pilski w znaczący sposób doświadczył likwidacji oferty połączeń pasażerskich, a następnie likwidacji linii kolejowych. W 1988 r. zlikwidowano połączenia na linii nr 378 Gołańcz - Chodzież, rok później połączenie Czarnkowa z Piłą, a cztery lata później z Poznaniem (przez Bzowo Goraj i Rogoźno). W 1992 r. likwidacji uległo połączenie Skoki - Janowiec (linii nr 385), a w 1996 r. Sława - Gniezno (377). W 1994 r. zlikwidowano połączenia Damasławka z Wągrowcem i Rogoźnem (206), a w 2000 r. Wapna z Damasławkiem i Gnieznem (281). Wyjątkiem jest linia z Piły do Wałcza (403), na której w 2000 r. ruch pasażerski zamknięto, aby siedem lat później z sukcesem go przywrócić (Drewnowski, Małachowski, 2015). Większość ze wspomnianych linii została fizycznie rozebrana. Ostatnie rozbiórki miały miejsce w latach 2016-2017. W 1992 r. zlikwidowano ruch pasażerski na

Tab. 1. Wybrane charakterystyki badanego obszaru.

\begin{tabular}{|c|c|c|c|c|c|c|}
\hline $\begin{array}{c}\text { Jednostka } \\
\text { administracyjna }\end{array}$ & $\begin{array}{l}\text { Liczba } \\
\text { ludności } \\
(2018)\end{array}$ & $\begin{array}{c}\text { Udział dzieci } \\
\text { i młodzieży } \\
\text { w wieku szkolnym } \\
\text { 6-18 lat [\%] (2018) }\end{array}$ & $\begin{array}{l}\text { Powierzchnia } \\
{\left[\mathrm{km}^{2}\right](2018)}\end{array}$ & $\begin{array}{c}\text { Gęstość } \\
\text { zaludnienia } \\
\text { [os./km²] } \\
(2018)\end{array}$ & $\begin{array}{c}\text { Stopa } \\
\text { bezrobocia } \\
{[\%]} \\
\text { (czerwiec } \\
\text { 2019) }\end{array}$ & $\begin{array}{c}\text { Liczba } \\
\text { samochodów } \\
\text { osobowych } \\
/ 1000 \\
\text { mieszkańców } \\
\text { (2017) }\end{array}$ \\
\hline Powiat chodzieski & 47229 & 14,43 & 685 & 69 & 6,2 & 701,8 \\
\hline $\begin{array}{l}\text { Powiat } \\
\text { czarnkowsko-trzcianecki }\end{array}$ & 87420 & 14,59 & 1806 & 48 & 4,0 & 645,6 \\
\hline Powiat pilski & 136621 & 13,99 & 1268 & 108 & 4,4 & 569,9 \\
\hline Powiat wągrowiecki & 70274 & 15,01 & 1040 & 68 & 4,8 & 670,9 \\
\hline Powiat złotowski & 69606 & 14,27 & 1660 & 42 & 5,7 & 538,0 \\
\hline Podregion pilski & 411150 & 14,39 & 6458 & 64 & 4,9 & 613,0 \\
\hline $\begin{array}{l}\text { Województwo } \\
\text { wielkopolskie }\end{array}$ & 3493969 & 13,85 & 29826 & 117 & 2,9 & 647,5 \\
\hline
\end{tabular}

Źródło: opracowanie własne na podstawie GUS.

\section{Infrastruktura transportowa podregionu}

Podstawę sieci transportu kołowego badanego obszaru stanowią drogi krajowe DK10, DK11 i DK22, z których największe znaczenie dla regionu mają dwie pierwsze. Tylko licząca niespełna 8 km obwodnica Wyrzyska w powiecie pilskim posiada status drogi ekspresowej. Drogi krajowe łączą tylko cztery z sześciu miast powiatowych. Transport samochodowy wewnątrz podregionu zapewniają więc drogi wojewódzkie i powiatowe, w zdecydowanej długości jednojezdniowe. Infrastruktura drogowa nie stanowi liniach wąskotorowych Bydgosko-Wyrzyskich Kolei Dojazdowych, jednak w 2001 r. na wybranych odcinkach przywrócono ruch turystyczny.

Likwidacja miała spotkać także połączenie z Poznania do Bydgoszczy przez Wągrowiec i Gołańcz, jednak w latach 2011-2013 z inicjatywy władz samorządowych województwa PKP PLK S.A. przeprowadziły ze środków RPO modernizację fragmentu niezelektryfikowanej linii kolejowej nr 356. Prace objęły odcinek Poznań-Wschód - Wągrowiec, podnosząc prędkość maksymalną pociągów do 120 km/h. Ruch pasażerski na skutek modernizacji wzrósł trzykrotnie, 
a inwestycja stała się symbolem sukcesu (Bul, Resiński, 2014). Warto odnotować fakt, że po remoncie przywrócono połączenia pasażerskie na fragmencie linii 206, między Wągrowcem a Rogoźnem, umożliwiając przesiadki na pociągi do Poznania i Piły.

Linia nr 354 z Poznania do Piły w momencie prowadzenia badań pozostawała w modernizacji, oferując niskie prędkości maksymalne. Na pozostałych czynnych w ruchu pasażerskim liniach kolejowych $(18,203,405)$ dominuje w miarę atrakcyjna dla podróży regionalnych maksymalna prędkość $100 \mathrm{~km} / \mathrm{h}$. Wyjątkiem są fragmenty linii nr 356 z Wągrowca do Gołańczy $(50$ km/h) oraz linii nr 403 z Piły do Wałcza $(80 \mathrm{~km} / \mathrm{h})$.

Poza infrastrukturą sieciową zmiany dotyczą również obiektów infrastruktury pasażerskiej. Choć dominującym trendem jest zamykanie dworców kolejowych na prowincji to zdarzają się wyjątki. Polskie Koleje Państwowe S.A. w 2013 r. poddały modernizacji dworzec w Chodzieży, a w 2016 r. dworzec Piła Główna. Miasto Wągrowiec natomiast zmodernizowało w 2015 r. dworzec kolejowy czyniąc z niego zintegrowane centrum komunikacyjne, łączące kolej, autobusy regionalne i autobusy miejskie. Prace były sfinansowane $z$ inicjatywy JESSICA, a efekt został nagrodzony przez Fundację ProKolej i Fundację Grupy PKP tytułem „Dworzec Roku 2018”.

Zamykanie obiektów dotyczy również dworców autobusowych, a nieliczne przebudowy mają silnie komercyjny charakter. W 2012 r. przebudowie poddano dworzec PKS w Złotowie, na terenie którego zlokalizowano sklep Netto, a rok później w Chodzieży, gdzie otwarto sklep Intermarche. W 2013 r. UMiG Margonin wybudował przystanek-poczekalnię dla pasażerów autobusów. Nawiązuje ona do licznych w północnej Wielkopolsce małych poczekalni przy dworcach autobusowych lub głównych przystankach w mieście (np. w Szamocinie), które powstawały w latach 70. XX w.

\section{Dostępność ekonomiczna}

Obsługę transportową podregionu pilskiego na sieci kolejowej zapewniają Przewozy Regionalne, Koleje Wielkopolskie, PKP Intercity, a także Wyrzyska Kolej Powiatowa. Wśród przedsiębiorstw autobusowych dominują spółki funkcjonujące $w$ dawnym województwie pilskim, powstałe na bazie Państwowej Komunikacji Samochodowej - PKS Piła i PKS Wałcz. Pewną rolę odrywają też przewoźnicy z sąsiednich podregionów, m.in. PKS Chojnice, PKS Poznań czy PKS Złocieniec. Badania prowadzone były w okresie następującym kilkanaście dni po zawieszeniu wszystkich kursów przez PKS Gniezno, obsługujące głównie wschodnią część podregionu. Ofertę przewozów autobusowych w subregionie uzupełniały prywatne przedsiębiorstwa AD EuroTrans, Autocentrum, Badura-Małuch, Baltic Sea Trans, Jozin-Trans, Novabus (d. Rafbus), Piotruś-Tour, Poznański Bus, Usługi Transportowe "M.K. Krüger Justyna Winniczuk". Niewielkie znaczenie dla spójności wewnętrznej podregionu ma także oferta przedsiębiorstw oferujących długodystansowe połączenia, zazwyczaj w taryfie pospiesznej, łączące miejscowości nadmorskie z ośrodkami w środkowej części kraju. Należą do nich m.in. PKS Bydgoszcz, PKS Chojnice, PKS Koszalin, PKS Polonus.

Przy okazji badań dostępności przestrzennej podregionu pilskiego dokonano również przeglądu taryf przewoźników lub organizatorów publicznego transportu zbiorowego. Zestawienie podstawowych taryf, z pominięciem taryf specjalnych oraz taryf na autobusy pospieszne, prezentują tab. 2 i 3.

Tab. 2. Taryfy podstawowe - normalne bilety jednorazowe [wartości w zł].

\begin{tabular}{|c|c|c|c|c|c|c|c|c|c|c|c|}
\hline 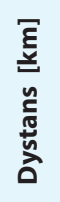 & 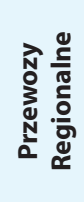 & 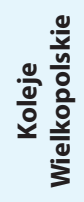 & 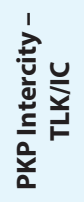 & $\begin{array}{l}\frac{0}{\frac{\pi}{\alpha}} \\
\frac{\tilde{y}}{\alpha}\end{array}$ & $\begin{array}{l}\frac{N}{N} \\
\frac{N}{n} \\
\frac{y}{a}\end{array}$ & 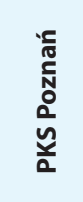 & 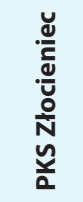 & 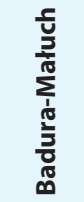 & 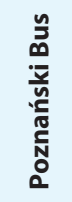 & 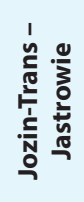 & 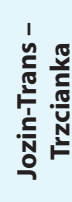 \\
\hline 5 & 4,00 & 4,00 & 13,00 & 5,00 & 7,40 & 4,40 & 4,70 & 5,00 & 4,00 & 5,00 & 6,00 \\
\hline 10 & 4,40 & 4,40 & 13,00 & 4,80 & 10,30 & 5,90 & 5,80 & 6,00 & 6,00 & 5,00 & 6,00 \\
\hline 15 & 5,30 & 5,30 & 13,00 & 7,00 & 11,70 & 7,40 & 6,50 & 7,00 & 7,00 & 6,00 & 7,00 \\
\hline 20 & 6,50 & 6,50 & 13,00 & 8,00 & 13,00 & 8,70 & 7,50 & 8,00 & 8,00 & 7,00 & 8,00 \\
\hline 30 & 8,20 & 8,20 & 13,00 & 10,00 & 15,40 & 11,30 & 10,70 & 10,00 & n.d. & 8,00 & n.d. \\
\hline 50 & 13,50 & 13,50 & 17,00 & 16,00 & 21,60 & 15,30 & 14,20 & 12,00 & n.d. & 9,00 & n.d. \\
\hline 100 & 19,80 & 19,80 & 29,00 & b.d. & 32,90 & b.d. & 22,50 & n.d. & n.d. & n.d. & n.d. \\
\hline
\end{tabular}

Źródło: opracowanie własne na podstawie cenników, stan w czerwcu 2019 r. 
Tab. 3. Taryfy podstawowe - normalne bilety miesięczne liniowe w obie strony [wartości w zł].

\begin{tabular}{|c|c|c|c|c|c|c|c|c|c|c|c|}
\hline 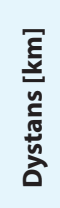 & 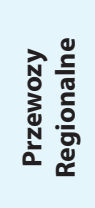 & 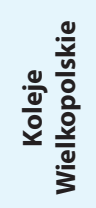 & 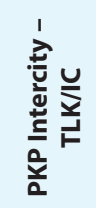 & $\begin{array}{l}\frac{0}{\frac{\pi}{a}} \\
\frac{\hat{y}}{a}\end{array}$ & 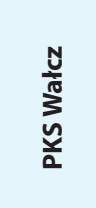 & 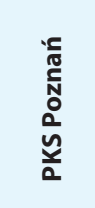 & 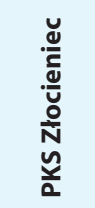 & $\begin{array}{l}\frac{5}{5} \\
\frac{5}{10} \\
\sum_{1}^{10} \\
\frac{1}{5} \\
\frac{5}{0} \\
\infty \\
\infty\end{array}$ & 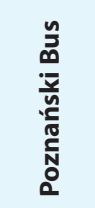 & 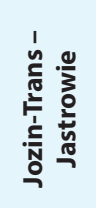 & 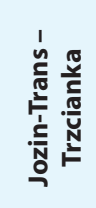 \\
\hline 5 & 93,00 & 93,00 & 248,00 & 150,00 & 199,80 & 137,00 & 149,00 & 120,00 & 90,00 & 90,00 & 110,00 \\
\hline 10 & 103,00 & 103,00 & 248,00 & 190,00 & 278,10 & 184,00 & 190,00 & 153,00 & 150,00 & 90,00 & 140,00 \\
\hline 15 & 144,00 & 144,00 & 248,00 & 210,00 & 315,90 & 230,00 & 215,00 & 193,00 & 180,00 & 110,00 & 160,00 \\
\hline 20 & 160,00 & 160,00 & 248,00 & 230,00 & 338,00 & 273,00 & 235,00 & 237,00 & 210,00 & 120,00 & 220,00 \\
\hline 30 & 197,00 & 197,00 & 248,00 & 260,00 & 400,00 & 357,00 & 300,00 & 285,00 & n.d. & 140,00 & n.d. \\
\hline 50 & 269,00 & 269,00 & 312,00 & 300,00 & 506,00 & 486,00 & 405,00 & 310,00 & n.d. & 150,00 & n.d. \\
\hline 100 & 326,00 & 326,00 & 412,00 & 350,00 & 606,00 & 819,00 & 510,00 & n.d. & n.d. & n.d. & n.d. \\
\hline
\end{tabular}

Źródło: opracowanie własne na podstawie cenników, stan w czerwcu 2019 r.

Najlepsze cenowo taryfy regionalne oferowali przewoźnicy kolejowi - Przewozy Regionalne oraz Koleje Wielkopolskie. Średnia cena jednorazowych biletów autobusowych analizowanych przewoźników była wyższa o 30-41\%, w zależności od dystansu, od regionalnej taryfy kolejowej. Natomiast cena biletów okresowych wynosiła jeszcze więcej - od 34\% do $75 \%$. Obaj regionalni przewoźnicy kolejowi oferowali możliwość wykupu półrocznej karty rabatowej pod nazwą „Karta Wielkopolska” w cenie 99 zł, dającej $15 \%$ rabatu na bilety okresowe i $30 \%$ na jednorazowe przejazdy na terenie województwa lub najbliższych stacji węzłowych. Karta jest stałym elementem oferty, wynikającym z umów z organizatorem transportu publicznego.

$\mathrm{Na}$ trasach, na których pojawiał się prywatny konkurent względem wieloletniego PKS, zazwyczaj obowiązywały taryfy specjalne, niższe od regularnych. Dotyczyło to np. połączeń między Piłą a Jastrowiem, obsługiwanych przez PKS Wałcz vs. Jozin-Trans (por. tab. 2 i 3). Historycznie, źle rozumiana konkurencja prowadziła w podregionie pilskim czasem do nielegalnych praktyk, jak podział rynku pomiędzy graczy. Przykładem mogą być działania PKS Piła i Rafbus w sprawie tras Rzadkowo - Kaczory - Piła i Białośliwie - Miasteczko Krajeńskie, które znalazły finał w decyzji nr RPZ 11/2018 Prezesa Urzędu Ochrony Konkurencji i Konsumentów nakładającej sankcje finansowe za zmowę.

W podregionie pilskim w pięciu miastach istniała lokalna oferta publicznego transportu zbiorowego, w trzech przypadkach autobusy wyjeżdżały poza granice administracyjne miasta (Chodzież, Piła, Wągrowiec). Cztery miasta organizowały ją poprzez własne przedsiębiorstwa, natomiast rozwiązanie innowacyjne w polskich warunkach zaoferował Złotów (tab. 4). Władze gminy miejskiej zawarły z przewoźnikami regionalnymi (PKS Piła, Jozin-Trans, Autocentrum, Baltic Sea Trans) porozumienie w sprawie zryczałtowanej taryfy miejskiej, wynoszącej w granicach administracyjnych 1,00 zł (tab. 4). Z kolei Wągrowiec w granicach administracyjnych miasta oferuje bezpłatne przejazdy dla wszystkich. Osobliwościami ofert są pełna integracja taryfowa między miastem

Tab. 4. Oferty w komunikacji miejskiej [wartości w zł].

\begin{tabular}{|l|c|c|c|c|}
\hline \multirow{2}{*}{ Przewoźnik } & \multicolumn{2}{|c|}{ Obszar miasta } & joza obszarem miasta \\
\cline { 2 - 5 } & jednorazowy & miesięczny & n.d. \\
\hline MZK Czarnków & 4,00 & 80,00 & 3,20 & 2,70 \\
\hline MZK Chodzież & 2,60 & 76,00 & 3,00 & 94,00 \\
\hline MZK Piła & 2,70 & 94,00 & 36,00 \\
\hline ZKM Wągrowiec & bezpłatny & bezpłatny & n.d. \\
\hline Złotów & 1,00 & n.d. & n.d. \\
\hline
\end{tabular}

Źródło: opracowanie własne na podstawie cenników, stan w czerwcu 2019 r. 
Piłą a gminą miejsko-wiejską Ujście, a także wymiar ulgi gminnej dla uczniów w Czarnkowie, która wynosi tylko $25 \%$.

W niniejszym artykule, przy analizach dostępności uwzględniono tylko te kursy, które umożliwiały przemieszczanie się pomiędzy gminami. Analiza dostępności do transportu publicznego w obrębie miast nie byłaby miarodajna w prowadzonych badaniach i wiązałaby się z koniecznością zastosowania innej metodyki (por. Soczówka, 2012, Gadziński, 2013, Połom, Goliszek, 2016).

\section{Dostępność ekonomiczna}

W związku z przyjętymi założeniami badań, tj. z perspektywy pasażera szukającego połączeń w dostępnych źródłach, przeanalizowano też dostęp do informacji o rozkładzie jazdy. Wszyscy przewoźnicy udostępniali informacje o rozkładzie. Żaden z lokalnych przewoźników autobusowych nie oferował natomiast własnej aplikacji. Z przewoźników kolejowych tę usługę posiadały Przewozy Regionalne i PKP Intercity (rozkład jazdy, sprzedaż biletów).

Działający w podregionie pilskim przewoźnicy autobusowi udostępniali telefoniczną informację o połączeniach. We wszystkich przypadkach dostępne były numery stacjonarne lub komórkowe, czyli funkcjonujące bez dodatkowych opłat (dostępne również w roamingu). Infolinie z podniesioną opłatą (tzw. usługi premium rate) oferowali wszyscy trzej przewoźnicy kolejowi (1,29 zł za minutę połączenia) oraz większość PKS-ów spoza regionu (np. PKS Poznań i PKS Chojnice - 2,08 zł/min; PKS Polonus i AD Euro-Trans - 2,58 zł/min).

Istotnym brakiem informacyjnym wielu małych przedsiębiorstw przewozowych było niezamieszczanie na stronie internetowej cennika usług. Dotyczyło to m.in. Baltic Sea Trans, Novabus czy MZK Czarnków.

\section{Dostępność przestrzenna}

Najwyższą dostępnością do transportu kolejowego cechował się powiat złotowski. 57\% mieszkańców regionu miało w swojej miejscowości czynną stację pasażerską. Wynikało to z faktu, iż przez powiat przebiegają dwie linie kolejowe, przy których zlokalizowane są jego największe miejscowości. Najgorszą dostępnością do kolei charakteryzował się powiat czarnkowsko-trzcianecki, w którym tylko 38\% mieszkańców było w zasięgu kolei. Drugie co do wielkości miasto powiatu - Czarnków, doświadczyło likwidacji linii kolejowych. W pozostałych powiatach blisko połowa mieszkańców miała dostęp do kolei.
Godnym podkreślenia jest stabilność rozkładów jazdy pociągów w czasie całego roku. Koleje normalnotorowe docierają do wszystkich miejscowości regionu we wszystkie dni tygodnia, zarówno w dni nauki szkolnej, jak i w czasie wakacji. Liczba kursów w weekendy nie jest radykalnie mniejsza niż w dni robocze. W związku z sezonowym uruchamianiem pociągów przez Wyrzyską Kolej Powiatową w weekendy ciepłego półrocza liczba miejscowości, a tym samym odsetek mieszkańców z dostępem do kolei, nieznacznie wzrasta.

W transporcie autobusowym zaobserwować można nastawienie na przewóz uczniów. Liczba kursów zdecydowanie spada poza dniami nauki szkolnej. Dotyczy to zarówno dni roboczych podczas wakacji, jak i weekendów. W skali całego podregionu pilskiego pozbawionych autobusowego transportu publicznego było $22 \%$ mieszkańców w dni powszednie w roku szkolnym, 44\% w dni powszednie podczas wakacji szkolnych, $60 \%$ w soboty i $63 \%$ w niedziele. $W$ dni nauki szkolnej najlepszą dostępnością charakteryzował się powiat chodzieski (10\% mieszkańców pozbawionych dostępu) oraz powiat czarnkowsko-trzcianecki (12\%). Najniższym poziomiem dostępności do autobusów regionalnych posiadał powiat wągrowiecki - 34\% mieszkańców nie miało w swych miejscowościach połączeń autobusowych. Choć powiat wągrowiecki dzięki Poznańskiej Kolei Metropolitalnej posiadał najatrakcyjniejszą ofertę kolejową, to jednak brak autobusów nie wynikał tylko z pomijania miejscowości mających dostęp do stacji kolejowych, ale głównie ze słabej oferty w pozostałych miejscowościach. Co więcej, w weekendy nie jeździł w powiecie żaden autobus regionalny. W dni robocze w czasie wakacji aż 60\% mieszkańców powiatu pozbawionych było połączeń autobusowych.

W układzie przestrzennym zaobserwować można (szczególnie uwidocznione poza dniami nauki szkolnej) zgrupowania miejscowości ze stosunkowo najlepszą obsługą autobusami regionalnymi. Są to kierunki: Piła - Złotów, Piła - Czarnków, Piła - Wałcz, Piła - Bydgoszcz (przez Miasteczko Krajeńskie, Łobżenicę lub Wyrzysk). Uzupełniają je połączenia kolejowe, których pozbawiona była tylko relacja do Czarnkowa.

Łączna dostępność obu form regionalnego transportu publicznego jest w dni robocze nieznacznie większa niż dostępność komunikacji autobusowej, a w weekendy niż dostępność komunikacji kolejowej. Wynika to z faktu, iż większość miejscowości obsługiwanych przez kolej posiada również połączenia autobusowe. Szczegółowe mapy dostępności kolejowego i autobusowego transportu publicznego przedstawiają ryc. 2-9, a szczegółowe dane dla poszczególnych gmin podregionu prezentują tab. 5-7. 


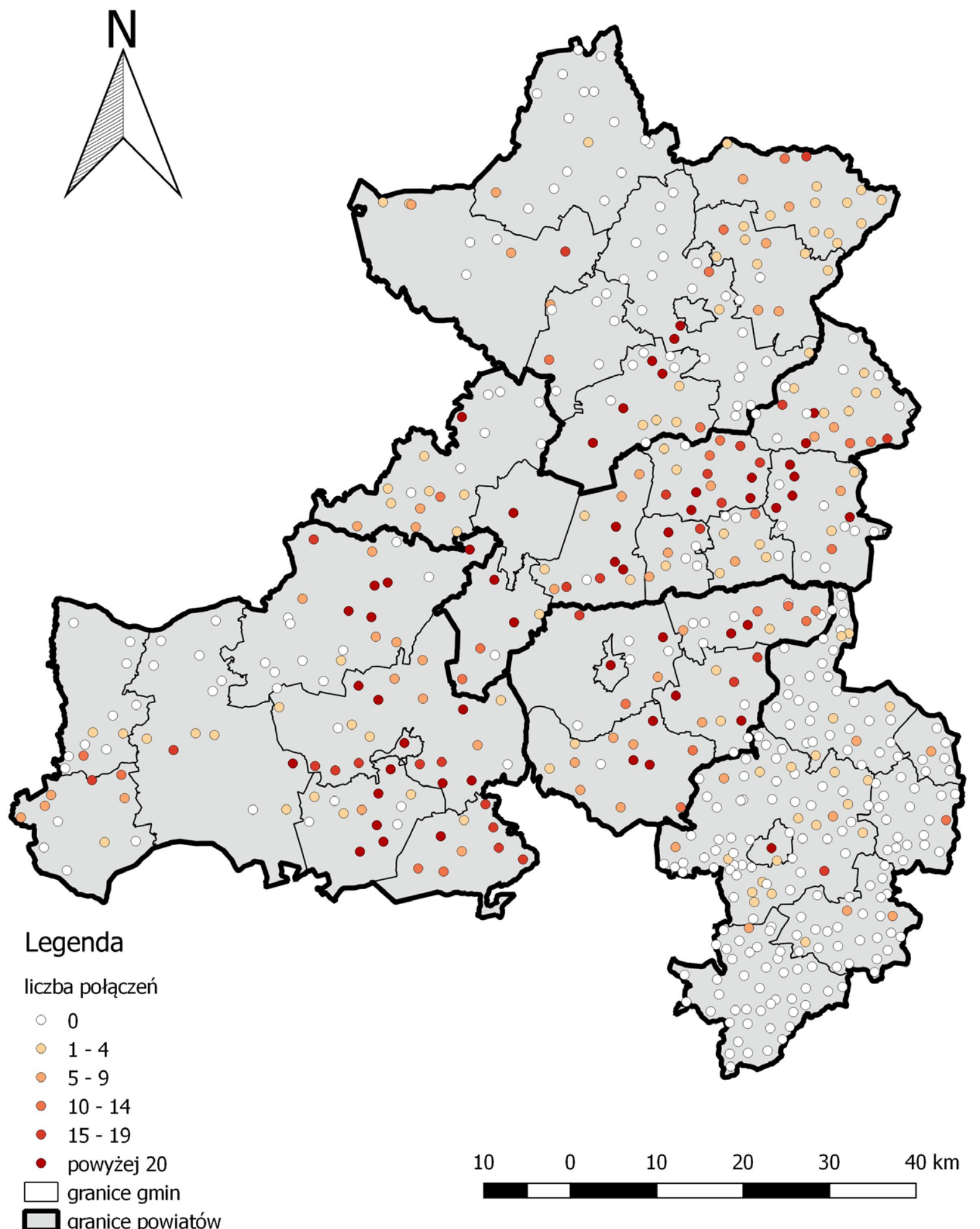

Ryc. 2. Dostępność podregionu pilskiego transportem autobusowym w dni robocze w czasie nauki szkolnej. Źródło: opracowanie własne. 


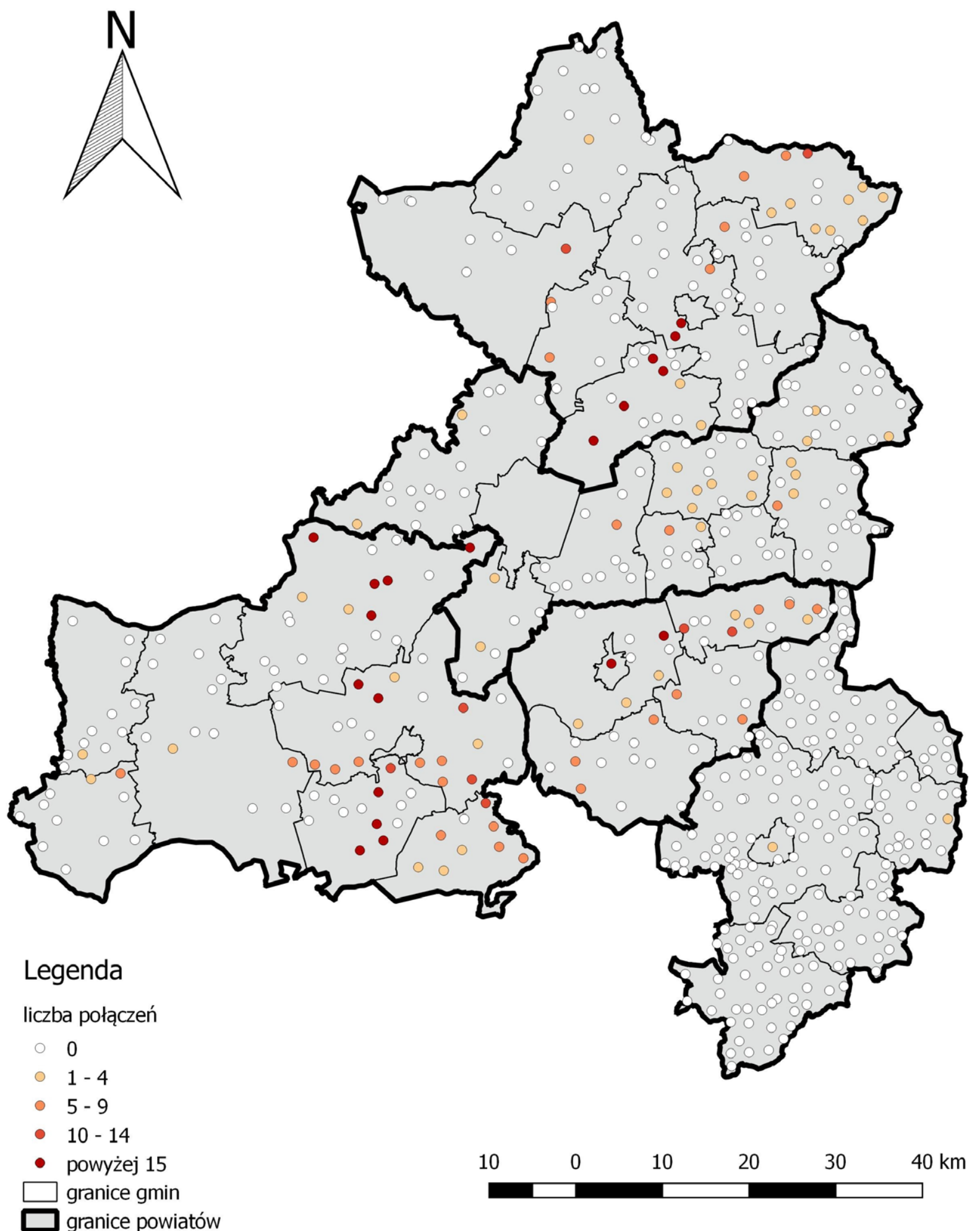

Ryc. 3. Dostępność podregionu pilskiego transportem autobusowym w dni robocze w czasie wakacji szkolnych. Źródło: opracowanie własne. 


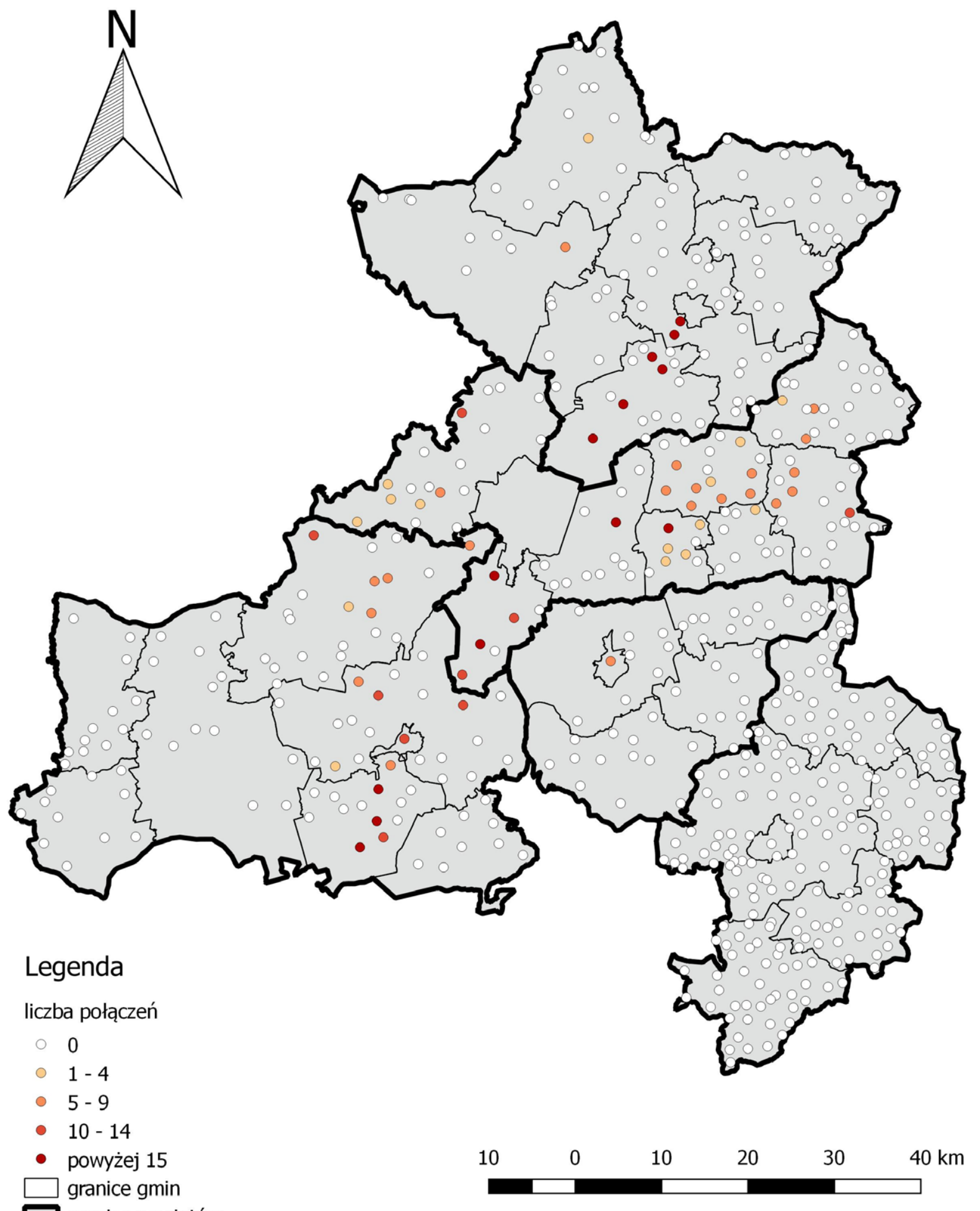

Ryc. 4. Dostępność podregionu pilskiego transportem autobusowym w soboty. Źródło: opracowanie własne. 


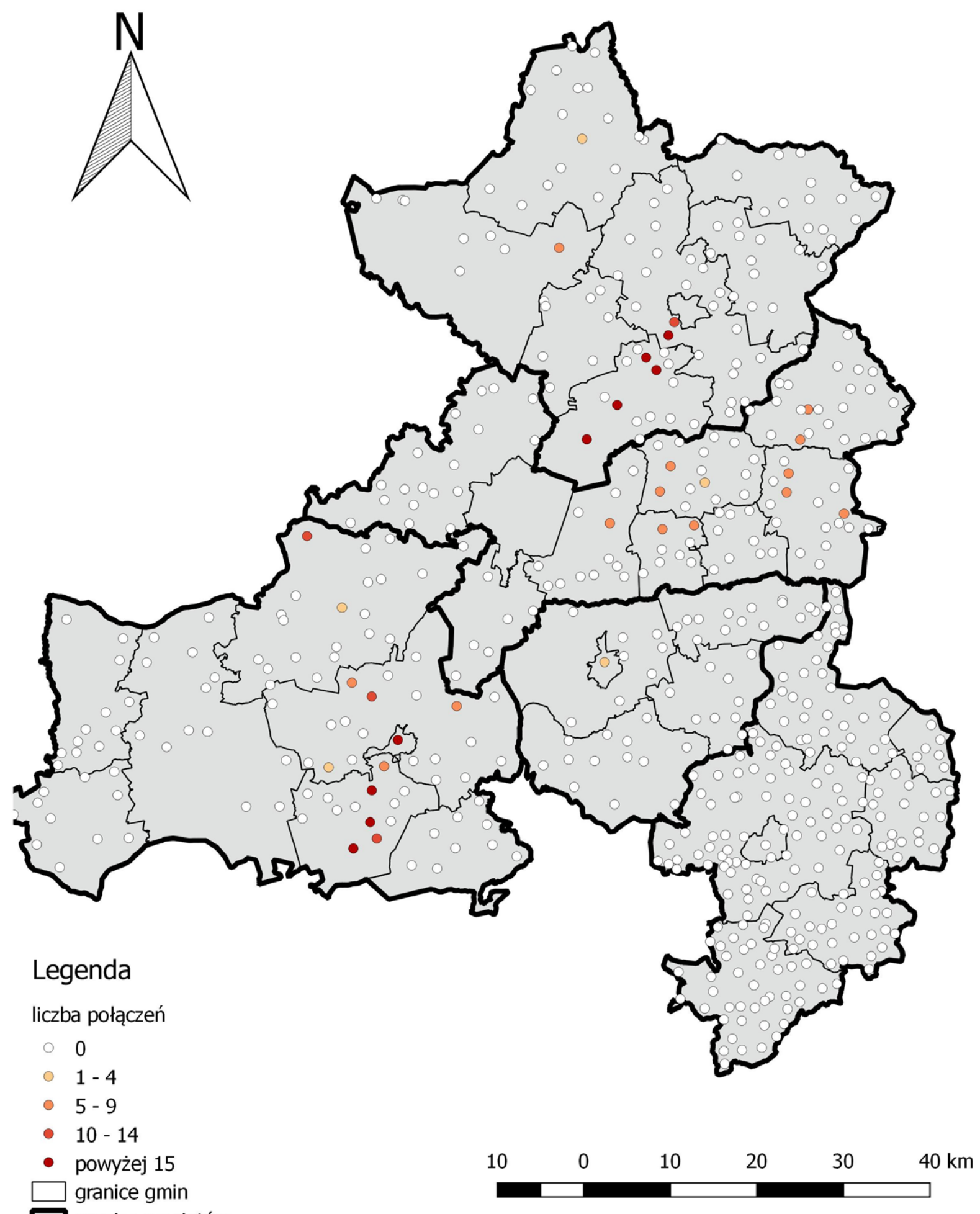

Ryc. 5. Dostępność podregionu pilskiego transportem autobusowym w niedziele.

Źródło: opracowanie własne. 

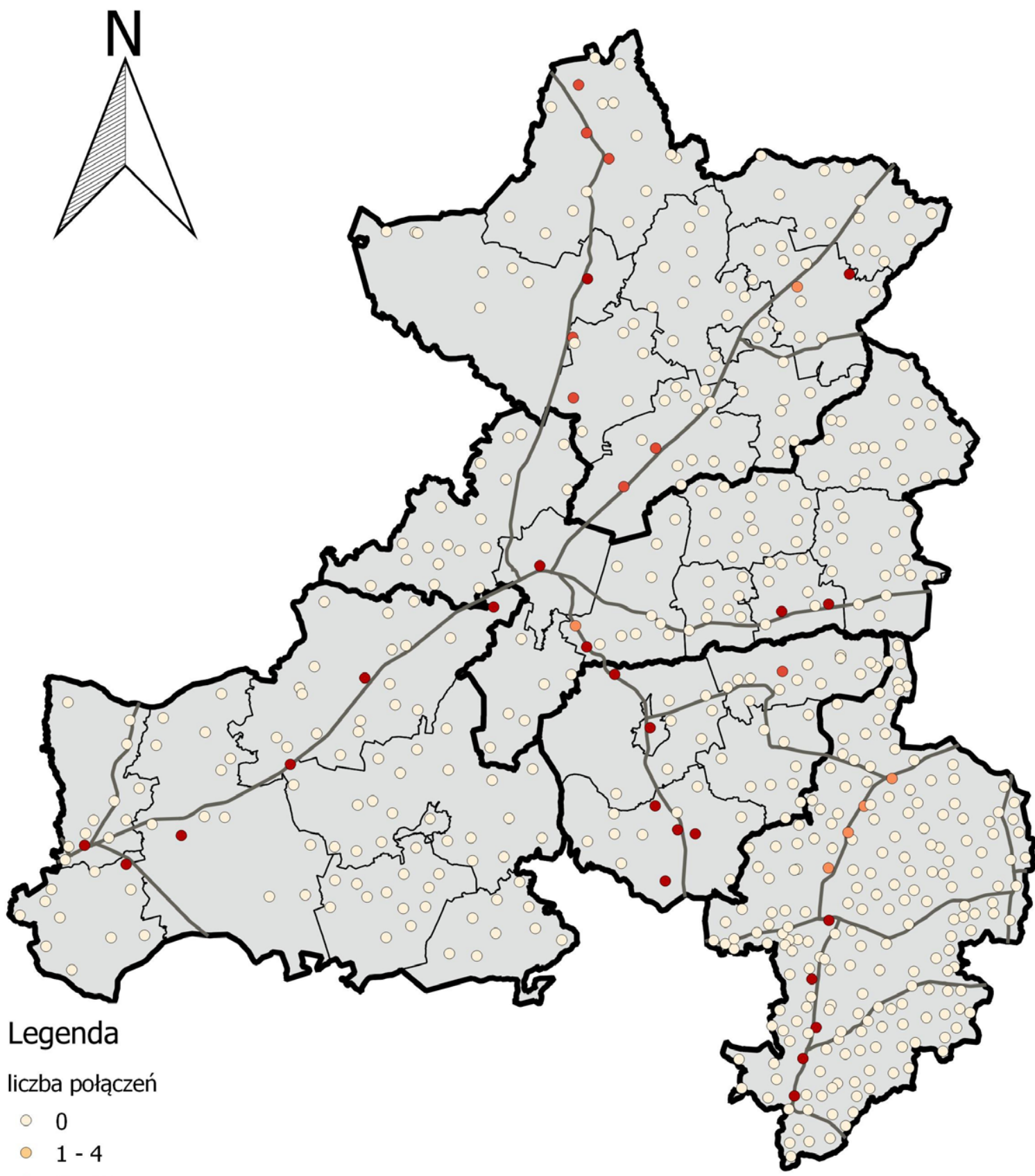

- 1 - 4

- $5-10$

- $10-14$

- powyżej 15

- sieć kolejowa granice gmin

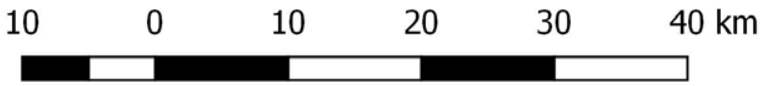

Ryc. 6. Dostępność podregionu pilskiego transportem kolejowym w dni robocze w czasie nauki szkolnej. Źródło: opracowanie własne. 

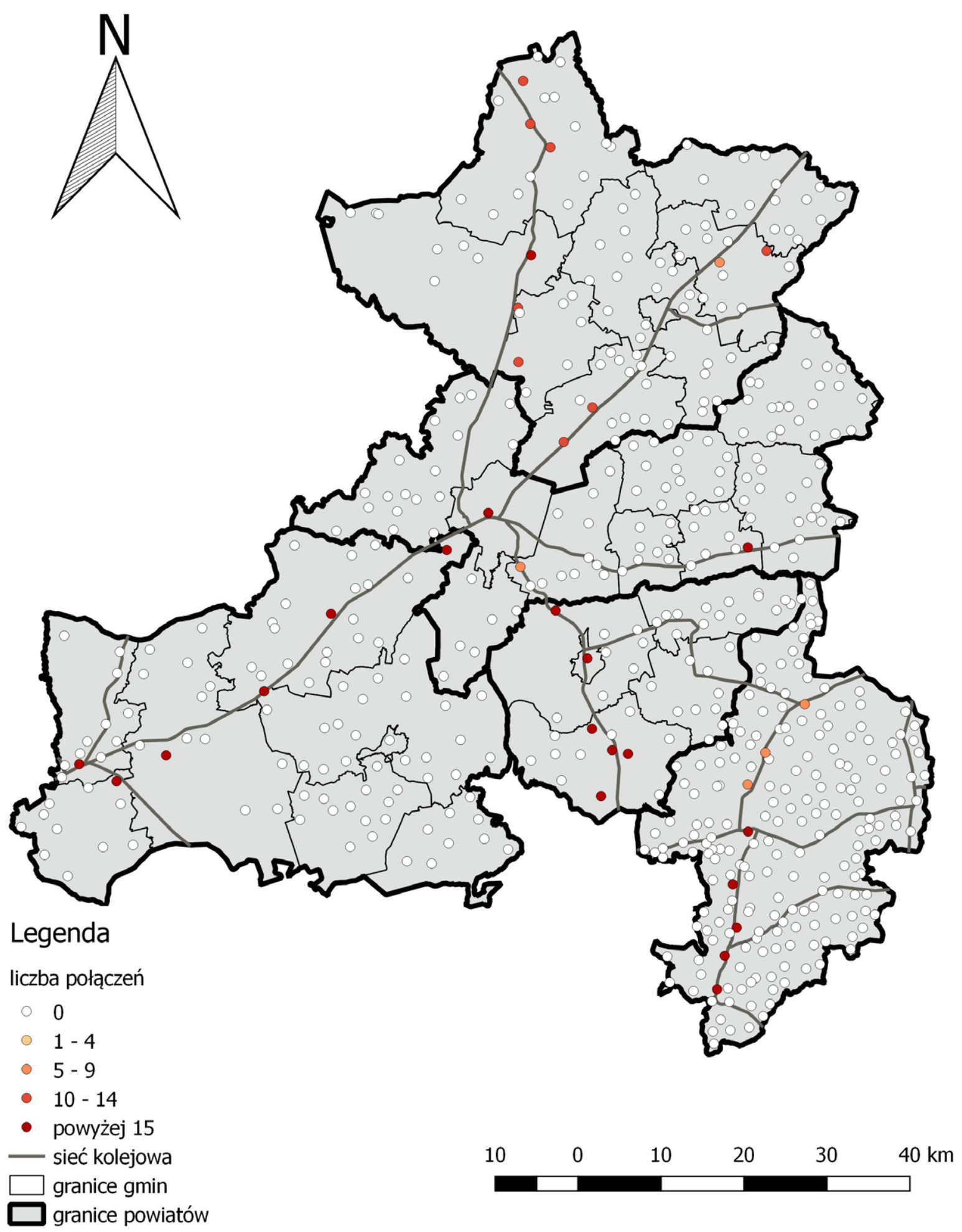

Ryc. 7. Dostępność podregionu pilskiego transportem autobusowym w dni robocze w czasie wakacji szkolnych. Źródło: opracowanie własne. 

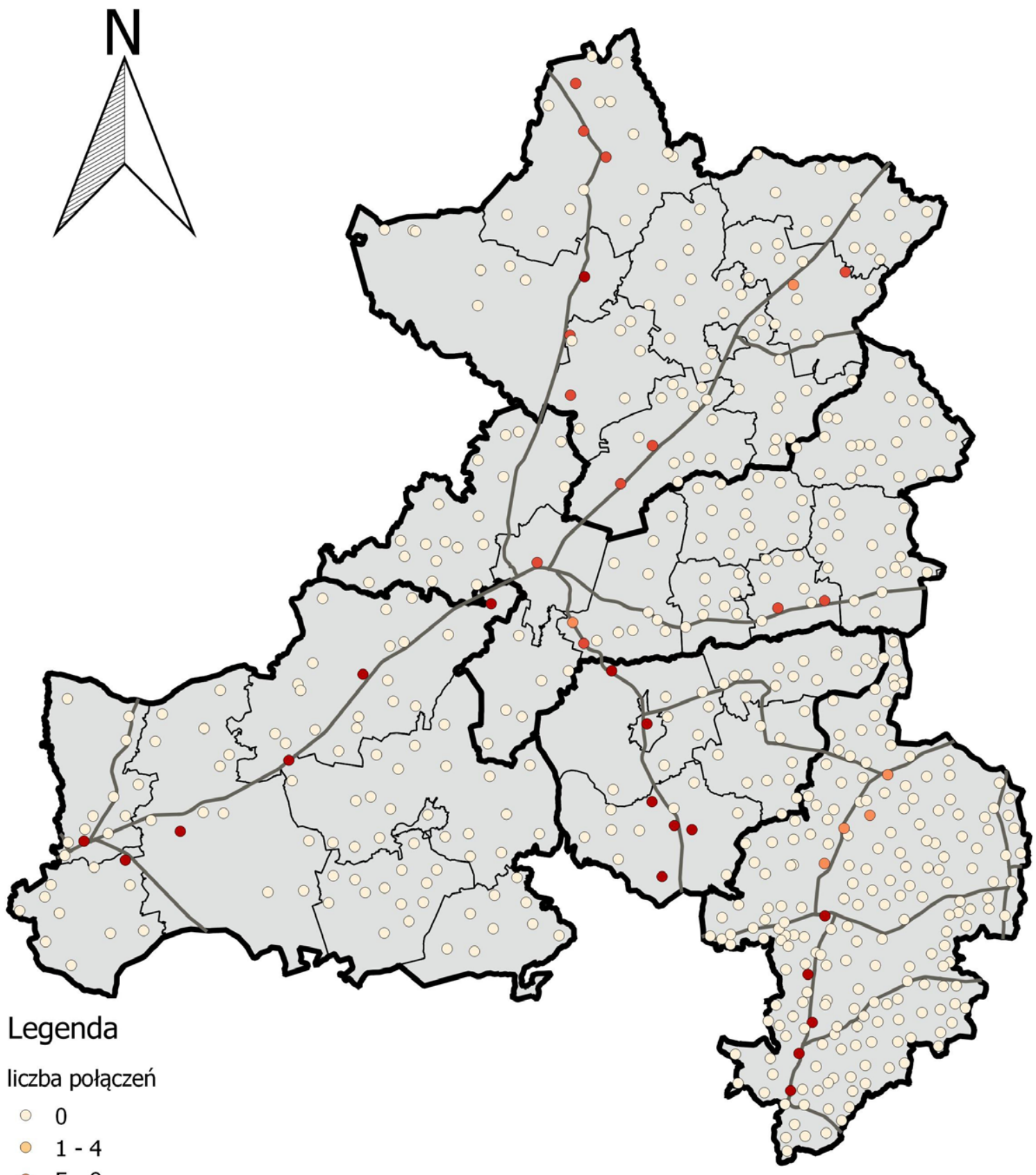

\section{Legenda}

liczba połączeń
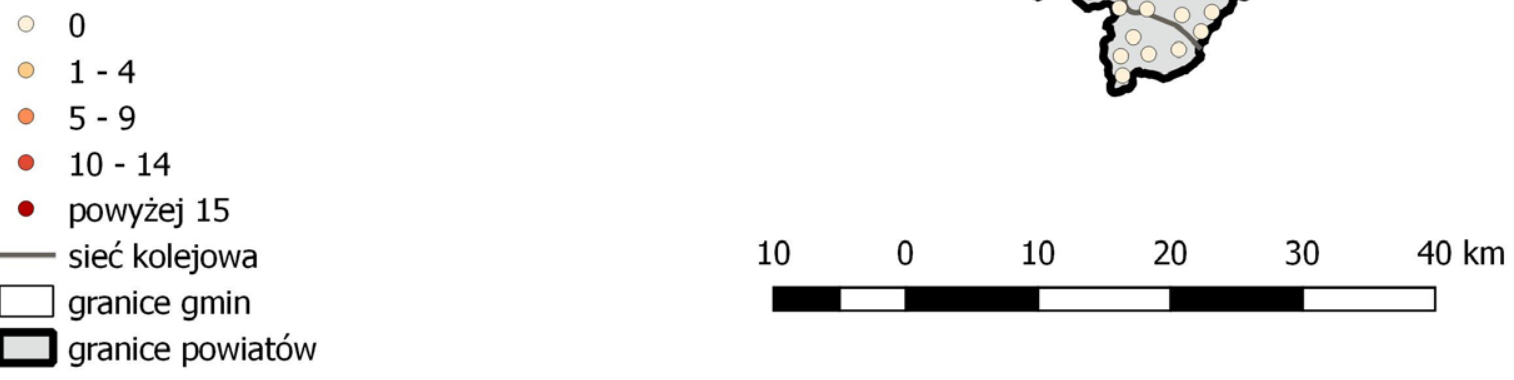

Ryc. 8. Dostępność podregionu pilskiego transportem autobusowym w soboty. 

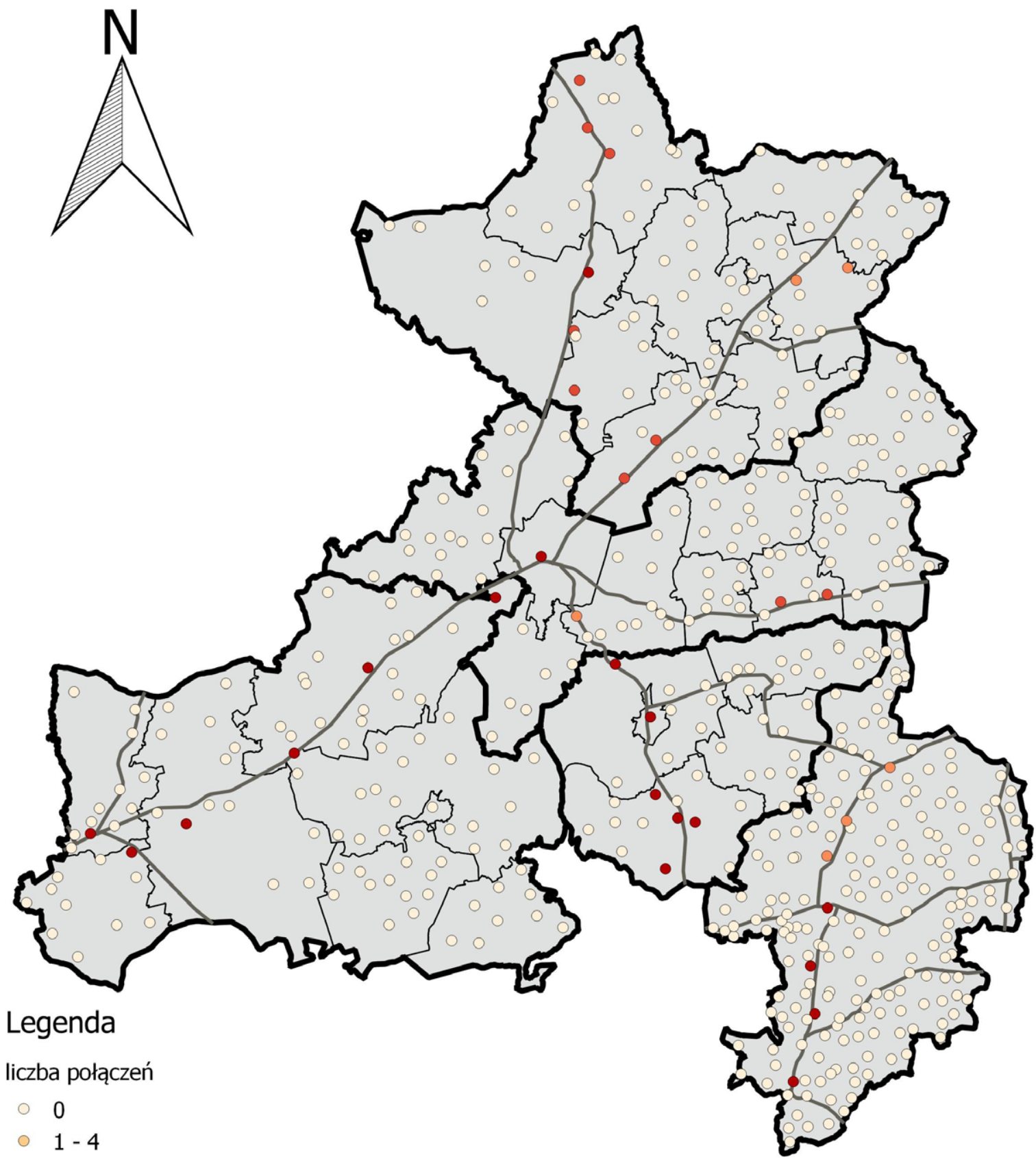

\section{Legenda}

liczba połączeń

- 0

- $1-4$

- $5-9$

- $10-14$

- powyżej 15

— sieć kolejowa granice gmin granice powiatów

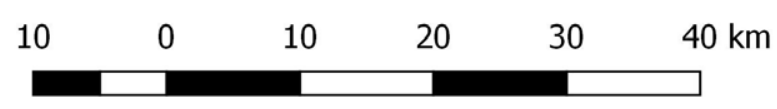

Ryc. 9. Dostępność podregionu pilskiego transportem autobusowym w niedziele. 


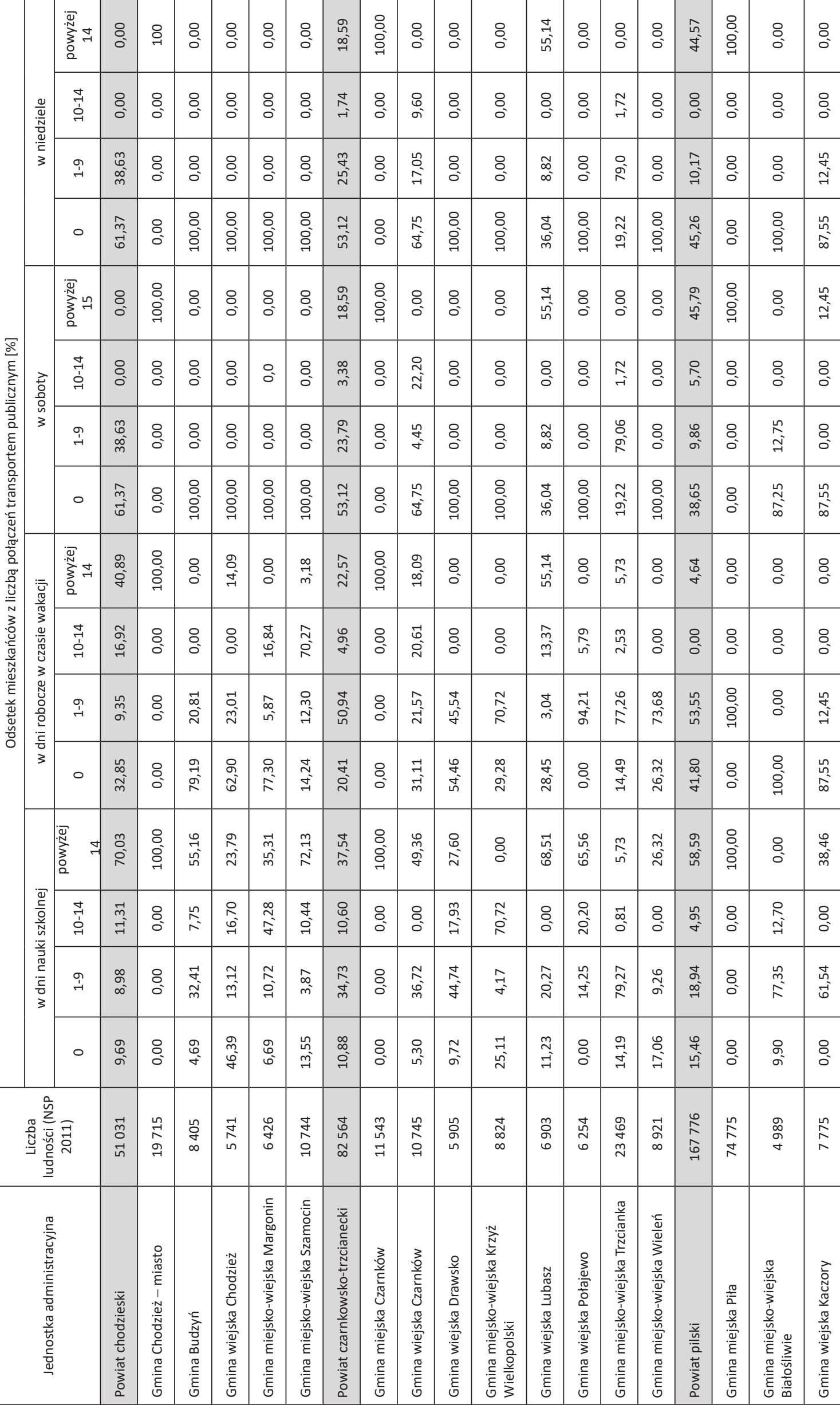




\begin{tabular}{|c|c|c|c|c|c|c|c|c|c|c|c|c|c|c|c|c|c|c|c|c|c|c|}
\hline 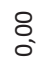 & o & : & $\begin{array}{l}8 \\
0 \\
0\end{array}$ & $\stackrel{8}{\circ}$ & : & 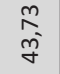 & $\begin{array}{l}\stackrel{2}{2} \\
\stackrel{2}{R}\end{array}$ & $\begin{array}{l}8 \\
0 \\
0\end{array}$ & o. & : & $\begin{array}{l}\stackrel{0}{\circ} \\
\stackrel{\infty}{\sigma}\end{array}$ & $\stackrel{8}{0}$ & 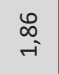 & 8 & 8 & 8 & $\begin{array}{l}8 \\
0 \\
0\end{array}$ & $\stackrel{\infty}{\leftrightarrow}$ & 8 & 永 & 8 & $\begin{array}{l}\text { : } \\
\text { ¿े }\end{array}$ \\
\hline 8 & : & 8 & 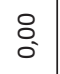 & $\stackrel{8}{8}$ & 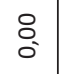 & 8 & $\begin{array}{l}8 \\
0 \\
0\end{array}$ & $\begin{array}{l}8 \\
0 \\
0\end{array}$ & 8 & $\begin{array}{l}8 \\
0 \\
0\end{array}$ & 8 & $\stackrel{8}{0}$ & $\begin{array}{l}8 \\
\dot{0}\end{array}$ & 8 & 8 & 8 & $\begin{array}{l}8 \\
0 \\
0\end{array}$ & $\underset{\sim}{\stackrel{\sim}{m}}$ & 8 & : & 8 & $\begin{array}{l}g \\
0 \\
0\end{array}$ \\
\hline $\begin{array}{l}\underset{N}{\tilde{N}} \\
\tilde{m}\end{array}$ & 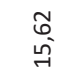 & $\stackrel{0}{0}$ & $\begin{array}{l}\hat{R} \\
\hat{\sigma}\end{array}$ & $\stackrel{\leftrightarrow}{m}$ & $\begin{array}{l}\infty \\
0 \\
\stackrel{d}{\sim}\end{array}$ & $\stackrel{8}{\leftrightarrow}$ & $\underset{\sim}{\stackrel{\sim}{\sim}}$ & 8 & $\begin{array}{l}\tilde{n} \\
\tilde{g} \\
\tilde{g}\end{array} \mid$ & $\begin{array}{l}8 \\
0 \\
0\end{array}$ & 8 & $\begin{array}{l}8 \\
0 \\
0\end{array}$ & 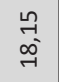 & 8 & 8 & 8 & $\begin{array}{l}8 \\
0\end{array}$ & 8 & $\mid \begin{array}{l}\infty \\
\infty \\
N \\
N\end{array}$ & \&. & $\begin{array}{l}\infty \\
\infty \\
f \\
f\end{array}$ & $\begin{array}{l}\hat{a} \\
\text { స్ }\end{array}$ \\
\hline \begin{tabular}{l}
$\stackrel{\infty}{\sim}$ \\
\multirow{6}{*}{}
\end{tabular} & 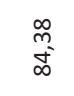 & $\begin{array}{l}\text { : } \\
\text { ò }\end{array}$ & 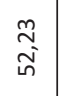 & $\begin{array}{l}\text { ơ } \\
\text { s }\end{array}$ & $\begin{array}{l}\tilde{N} \\
\tilde{n} \\
\tilde{n}\end{array}$ & $\begin{array}{l}\hat{6} \\
\stackrel{g}{\sigma}\end{array}$ & 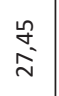 & $\begin{array}{l}8 \\
\stackrel{0}{0} \\
\stackrel{9}{1}\end{array}$ & $\begin{array}{l}\infty \\
0 \\
0 \\
i \\
\text { in }\end{array}$ & $\begin{array}{l}8 \\
0 \\
0 \\
9\end{array}$ & $\underset{\Im}{\stackrel{J}{~}}$ & $\begin{array}{l}8 \\
: \\
\stackrel{-}{0}\end{array}$ & 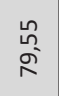 & $\mid \begin{array}{l}0 \\
0 \\
0 \\
0\end{array}$ & $\begin{array}{l}8 \\
\stackrel{0}{0} \\
0 \\
-1\end{array}$ & $\begin{array}{l}8 \\
: \\
0 \\
0\end{array}$ & $\begin{array}{l}8 \\
\stackrel{0}{0} \\
\text { a }\end{array}$ & \begin{tabular}{l}
$\stackrel{J}{J}$ \\
\multirow{J}{*}{}
\end{tabular} & 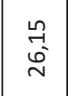 & $\begin{array}{l}\infty \\
\substack{\infty \\
\infty \\
\infty \\
\infty \\
\infty}\end{array}$ & 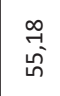 & 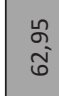 \\
\hline : & $\begin{array}{l}\text { Uू } \\
\text { ș }\end{array}$ & : & 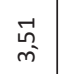 & : & $\begin{array}{l}8 \\
0 \\
0\end{array}$ & $\underset{\substack{m \\
\tilde{g}}}{ }$ & 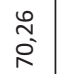 & $\begin{array}{l}8 \\
0 \\
0\end{array}$ & \& & $\begin{array}{l}8 \\
0 \\
0\end{array}$ & $\begin{array}{l}\stackrel{0}{2} \\
\stackrel{\infty}{\sigma}\end{array}$ & : & $\underset{m}{\sim}$ & o. & \& & : & $\begin{array}{l}8 \\
0 \\
0\end{array}$ & $\begin{array}{l}\infty \\
\infty \\
i\end{array}$ & $\begin{array}{l}8 \\
0\end{array}$ & $\underset{\text { ने }}{\text { f }}$ & 8 & 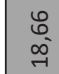 \\
\hline$\stackrel{0}{0}$ & 8 & $\underset{G}{\text { fo }}$ & $\begin{array}{l}\tilde{0} \\
\tilde{n} \\
n\end{array}$ & 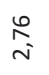 & $\begin{array}{l}8 \\
0 \\
0\end{array}$ & 8 & 8 & $\begin{array}{l}8 \\
0 \\
0\end{array}$ & 8 & $\begin{array}{l}8 \\
0 \\
0\end{array}$ & : & $\stackrel{\circ}{\circ}$ & $\stackrel{8}{\circ}$ & : & ㅇ. & 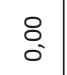 & $\stackrel{8}{8}$ & : & 8 & $\stackrel{8}{0}$ & 8 & $\stackrel{\substack{0 \\
m}}{m^{2}}$ \\
\hline $\begin{array}{c}\infty \\
\infty \\
\infty \\
\infty \\
\infty \\
m\end{array}$ & 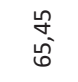 & $\begin{array}{l}\stackrel{\sim}{\infty} \\
\stackrel{d}{\sim}\end{array}$ & $\begin{array}{l}\stackrel{0}{\omega_{n}} \\
\sigma\end{array}$ & $\begin{array}{l}\stackrel{8}{+} \\
+\end{array}$ & 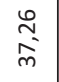 & $\stackrel{8}{0}$ & $\underset{\sim}{\stackrel{\sim}{\sim}}$ & $\begin{array}{l}8 \\
0 \\
0\end{array}$ & $\stackrel{\stackrel{n}{g}}{\tilde{g}}$ & $\begin{array}{l}8 \\
0 \\
0\end{array}$ & : & $\stackrel{8}{0}$ & $\begin{array}{l}\stackrel{\sim}{7} \\
\underset{\sim}{\infty}\end{array}$ & 8 & : & 8 & : & : & 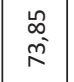 & 8 & $\begin{array}{l}\widetilde{\alpha} \\
\tilde{J} \\
\tilde{J}\end{array}$ & 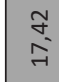 \\
\hline $\begin{array}{l}\approx \\
\overrightarrow{0}\end{array}$ & 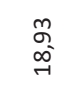 & 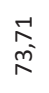 & $\begin{array}{l}\overrightarrow{\sigma^{2}} \\
\vec{m}\end{array}$ & $\stackrel{\infty}{\underset{\sigma}{\sigma}}$ & $\begin{array}{l}\stackrel{+}{\hat{\sigma}} \\
\hat{\sigma}\end{array}$ & $\begin{array}{l}\hat{6} \\
\stackrel{g}{g}\end{array}$ & 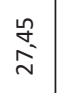 & $\begin{array}{l}\stackrel{8}{0} \\
\stackrel{-}{0}\end{array}$ & $\begin{array}{l}\infty \\
\stackrel{\infty}{+} \\
\text { i }\end{array}$ & $\begin{array}{l}0 \\
: \\
0 \\
0\end{array}$ & $\stackrel{+}{\stackrel{\sim}{n}}$ & $\begin{array}{l}\stackrel{8}{\circ} \\
\text { ò }\end{array}$ & ผn & $\begin{array}{l}8 \\
8 \\
0 \\
0\end{array}$ & $\begin{array}{l}\stackrel{8}{.} \\
\stackrel{్}{0}\end{array}$ & $\begin{array}{l}\stackrel{8}{\circ} \\
\stackrel{0}{0}\end{array}$ & $\begin{array}{l}\stackrel{8}{\circ} \\
\text { ò }\end{array}$ & \begin{tabular}{l}
$\stackrel{J}{*}$ \\
\multirow{J}{*}{}
\end{tabular} & $\mid \begin{array}{l}n \\
0 \\
\stackrel{n}{N}\end{array}$ & 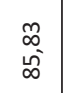 & $\begin{array}{l}\infty \\
\text { 足 } \\
\text { 足 }\end{array}$ & $\begin{array}{l}0 \\
\stackrel{0}{0} \\
0\end{array}$ \\
\hline$\stackrel{0}{0}$ & : & $\stackrel{0}{0}$ & 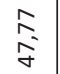 & : & $\begin{array}{l}8 \\
0 \\
0\end{array}$ & $\begin{array}{l}\stackrel{m}{o} \\
\stackrel{v}{v}\end{array}$ & $\begin{array}{l}\stackrel{2}{1} \\
\stackrel{2}{R}\end{array}$ & $\begin{array}{l}8 \\
0 \\
0\end{array}$ & 8 & $\stackrel{8}{8}$ & 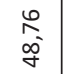 & : & $\underset{m}{\sim}$ & 8 & : & $:$ & : & $\begin{array}{l}\stackrel{0}{\infty} \\
\infty \\
i\end{array}$ & 8 & $\begin{array}{l}\text { ने } \\
\text { J }\end{array}$ & 8 & 욕 \\
\hline$:$ & : & : & : & : & $\begin{array}{l}8 \\
0 \\
0\end{array}$ & : & $\begin{array}{l}8 \\
0 \\
0\end{array}$ & $\begin{array}{l}8 \\
0 \\
0\end{array}$ & 8 & $\begin{array}{l}8 \\
0 \\
0\end{array}$ & 8 & : & $\begin{array}{l}\tilde{m} \\
\stackrel{\sim}{*}\end{array}$ & $\begin{array}{l}8 \\
0 \\
0\end{array}$ & 尽 & $\begin{array}{l}8 \\
0 \\
0\end{array}$ & $\begin{array}{l}8 \\
0 \\
0\end{array}$ & : & 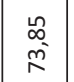 & : & 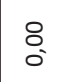 & 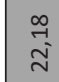 \\
\hline $\begin{array}{l}\text { প్ } \\
\text { g্ }\end{array}$ & 鸽 & $\underset{\substack{0 \\
\leftarrow}}{+}$ & $\underset{\infty}{\stackrel{0}{\infty}}$ & ت્ & $\begin{array}{l}\stackrel{2}{\sim} \\
\stackrel{n}{m}\end{array}$ & 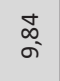 & $\overrightarrow{\tilde{m}}$ & 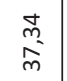 & $\begin{array}{l}\stackrel{R}{0} \\
\dot{g}\end{array}$ & o. & 8 & $\underset{m}{q}$ & $\stackrel{\infty}{\stackrel{\infty}{二}}$ & 8 & $\begin{array}{l}\stackrel{\infty}{\not} \\
\stackrel{7}{7}\end{array}$ & $\begin{array}{l}8 \\
0 \\
0\end{array}$ & $\begin{array}{l}\mathbb{I} \\
\stackrel{ज}{I}\end{array}$ & 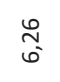 & 8 & ô. & $\begin{array}{l}\sim \\
\infty \\
\sim \\
f\end{array}$ & 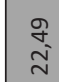 \\
\hline 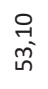 & $\begin{array}{l}\infty \\
\substack{n \\
n \\
n}\end{array}$ & $\begin{array}{l}\text { 早 } \\
\text { s. }\end{array}$ & $\underset{\text { q }}{\tilde{g}}$ & $\begin{array}{l}\stackrel{0}{\infty} \\
\tilde{\sigma}^{-}\end{array}$ & $\begin{array}{l}\stackrel{+}{\hat{N}} \\
\hat{\sigma}\end{array}$ & $\underset{\substack{m \\
g \\
g}}{ }$ & 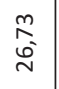 & 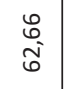 & $\begin{array}{l}\text { O্. } \\
\text { ભે }\end{array}$ & $\begin{array}{l}8 \\
\text { o } \\
\text { : }\end{array}$ & $\underset{ت}{\stackrel{J}{N}}$ & $\begin{array}{l}\hat{n} \\
\text { s̆ }\end{array}$ & \begin{tabular}{l}
8 \\
8 \\
6 \\
\hdashline
\end{tabular} & $\begin{array}{l}8 \\
0 \\
0 \\
0\end{array}$ & 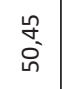 & $\begin{array}{l}0 \\
\stackrel{0}{0} \\
心 \\
\infty\end{array}$ & $\begin{array}{l}\mathscr{8} \\
\tilde{1} \\
\infty\end{array}$ & $\begin{array}{l}\stackrel{0}{\infty} \\
\stackrel{\infty}{\infty}\end{array}$ & 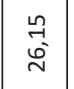 & $\begin{array}{l}\stackrel{0}{\circ} \\
\stackrel{\sim}{0}\end{array}$ & 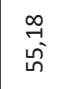 & $\begin{array}{l}\tilde{N} \\
\underset{f}{f}\end{array}$ \\
\hline $\begin{array}{l}\text { \&. } \\
\text { gे }\end{array}$ & 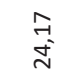 & $\underset{\mathrm{F}}{\mathrm{f}}$ & $\begin{array}{l}8 \\
\stackrel{8}{0} \\
0\end{array}$ & $\stackrel{\Re}{r}$ & $\begin{array}{l}\vec{A} \\
\underset{J}{f}\end{array}$ & \begin{tabular}{l}
$\vec{\infty}$ \\
\multirow{J}{J}{}
\end{tabular} & 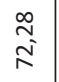 & : & 8 & 8 & $\begin{array}{l}\stackrel{0}{2} \\
\stackrel{\infty}{\sigma}\end{array}$ & 8 & 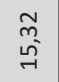 & 8 & $\hat{\therefore}$ & 8 & 8 & $\begin{array}{l}\mathscr{0} \\
\infty \\
\text { in }\end{array}$ & $\mid \begin{array}{l}\infty \\
\infty \\
N \\
N\end{array}$ & 拿 & $\therefore$ & 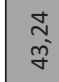 \\
\hline$\stackrel{\stackrel{L}{N}}{N}$ & $\underset{m}{g}$ & $\begin{array}{l}\infty \\
\sigma \\
\sigma\end{array}$ & $\begin{array}{l}\stackrel{\leftrightarrow}{\leftrightarrow} \\
\text { s. }\end{array}$ & 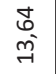 & $\begin{array}{l}\mathscr{\leftarrow} \\
\stackrel{\leftarrow}{*}\end{array}$ & $\begin{array}{l}\infty \\
\stackrel{2}{\sigma}\end{array}$ & $\underset{\sim}{\stackrel{\sim}{\sim}}$ & $\underset{m}{\stackrel{n}{m}}$ & స్ & 8 & 8 & 8 & $\underset{\infty}{\stackrel{9}{-1}}$ & 8 & $\underset{\sim}{\stackrel{\overbrace{}}{\rightarrow}}$ & $\begin{array}{l}8 \\
8 \\
0\end{array}$ & 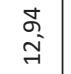 & $\begin{array}{l}\stackrel{0}{ } \\
\underset{\sigma}{\sigma}\end{array}$ & 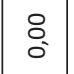 & $\begin{array}{l}\text { o } \\
\text { s. } \\
i^{\circ}\end{array}$ & 8 & $\begin{array}{l}\hat{b} \\
\infty^{\circ}\end{array}$ \\
\hline $\begin{array}{l}\text { న్ } \\
\text { స్ }\end{array}$ & 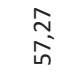 & 亲 & 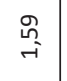 & 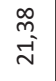 & $\begin{array}{l}\stackrel{M}{f} \\
f\end{array}$ & $\begin{array}{l}\underset{\sim}{d} \\
\underset{d}{d}\end{array}$ & $\begin{array}{l}\tilde{m} \\
\stackrel{n}{\sim} \\
\stackrel{\sim}{n}\end{array}$ & 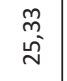 & $\begin{array}{l}\vec{n} \\
\underset{\sim}{\tilde{n}}\end{array}$ & $\begin{array}{l}-1 \\
\infty \\
\infty \\
n\end{array}$ & $\underset{J}{\mathrm{f}}$ & 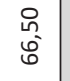 & $\begin{array}{l}\stackrel{0}{1} \\
\stackrel{n}{n}\end{array}$ & $\begin{array}{l}8 \\
0 \\
0 \\
0\end{array}$ & $\begin{array}{l}\tilde{m}_{0} \\
\stackrel{\infty}{\infty}\end{array}$ & $\stackrel{\circ}{\stackrel{0}{n}}$ & 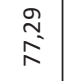 & $\begin{array}{l}\stackrel{0}{2} \\
\text { in }\end{array}$ & $\left|\begin{array}{c}\stackrel{9}{2} \\
\infty \\
\sim \\
\sim\end{array}\right|$ & 売 & $\begin{array}{l}\stackrel{\mu}{\mu} \\
\text { g. }\end{array}$ & 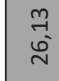 \\
\hline 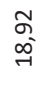 & $\begin{array}{l}\text { iे } \\
\text { si }\end{array}$ & $\begin{array}{l}\mathbb{E} \\
\text { s. }\end{array}$ & $\underset{\stackrel{m}{\tilde{m}}}{\vec{m}}$ & $\begin{array}{l}\text { 总 } \\
\text { in }\end{array}$ & $\stackrel{8}{0}$ & 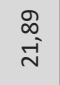 & 总 & 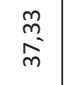 & $\begin{array}{l}n \\
\text { ñ } \\
\text { m. }\end{array}$ & $\begin{array}{l}\stackrel{g}{\vec{f}} \\
\stackrel{\vec{f}}{ }\end{array}$ & $\begin{array}{l}\hat{\sigma} \\
\text { g }\end{array}$ & $\underset{\substack{0 \\
\text { m. }}}{\text { D. }}$ & 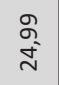 & 8 & 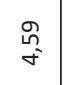 & $\begin{array}{l}0 \\
0 \\
0 \\
\infty \\
\infty\end{array}$ & $\underset{\sigma}{k}$ & $\underset{\infty}{\stackrel{m}{j}}$ & $\stackrel{\infty}{\stackrel{\infty}{\wedge}}$ & $\stackrel{\tilde{J}}{\exists}$ & $\begin{array}{l}\text { fo } \\
\text { ci } \\
\text { in }\end{array}$ & 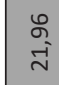 \\
\hline 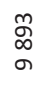 & 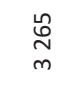 & $\underset{\infty}{\hat{y}}$ & $\begin{array}{l}\stackrel{0}{0} \\
\stackrel{\sim}{-1}\end{array}$ & $\begin{array}{l}\overrightarrow{0} \\
\overrightarrow{0} \\
\stackrel{D}{\sim}\end{array}$ & $\begin{array}{l}\underset{N}{N} \\
\underset{\exists}{ }\end{array}$ & $\begin{array}{l}\text { ஃ } \\
\infty \\
\infty \\
0\end{array}$ & 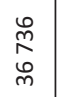 & $\begin{array}{l}\stackrel{0}{0} \\
i \\
i\end{array}$ & \begin{tabular}{l}
$\infty$ \\
\multirow{1}{\infty}{} \\
$\infty$
\end{tabular} & $\begin{array}{l}\text { fo } \\
0\end{array}$ & 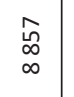 & $\begin{array}{l}0 \\
\stackrel{7}{m}\end{array}$ & $\begin{array}{l}\vec{N} \\
\stackrel{2}{R}\end{array}$ & $\begin{array}{l}0 \\
\stackrel{0}{0} \\
\infty \\
\sim\end{array}$ & $\begin{array}{l}\vec{b} \\
i \\
i n\end{array}$ & $\underset{m}{m}$ & $\begin{array}{l}\text { శ్ } \\
\sigma\end{array}$ & $\begin{array}{l}\hat{g} \\
\sigma \\
\sigma\end{array}$ & $\begin{array}{l}\vec{D} \\
\vec{A} \\
\overrightarrow{7}\end{array}$ & 莴 & 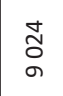 & $\begin{array}{l}\mathcal{F} \\
\text { f } \\
\text { g }\end{array}$ \\
\hline 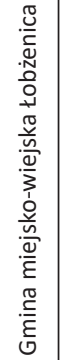 & 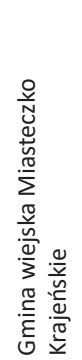 & 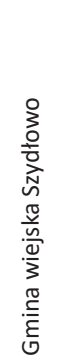 & 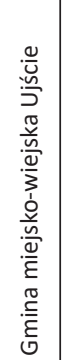 & 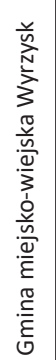 & 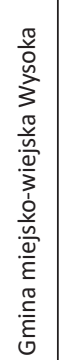 & 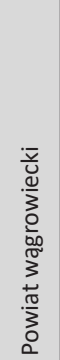 & 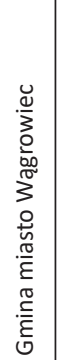 & 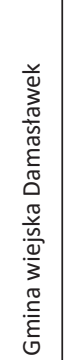 & 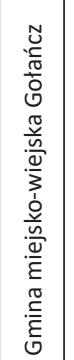 & 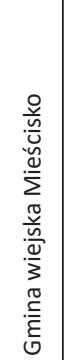 & 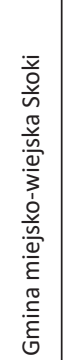 & 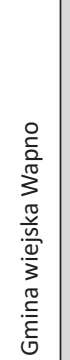 & 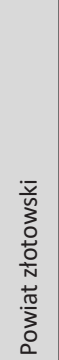 & 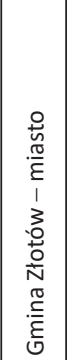 & 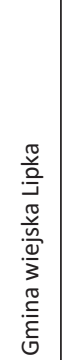 & 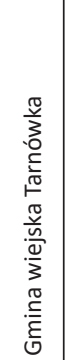 & 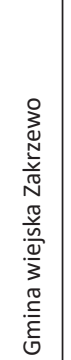 & 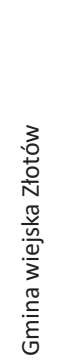 & 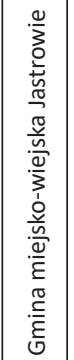 & 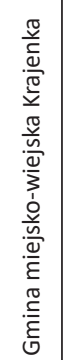 & 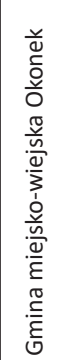 & 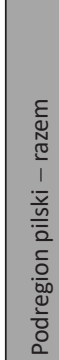 \\
\hline
\end{tabular}




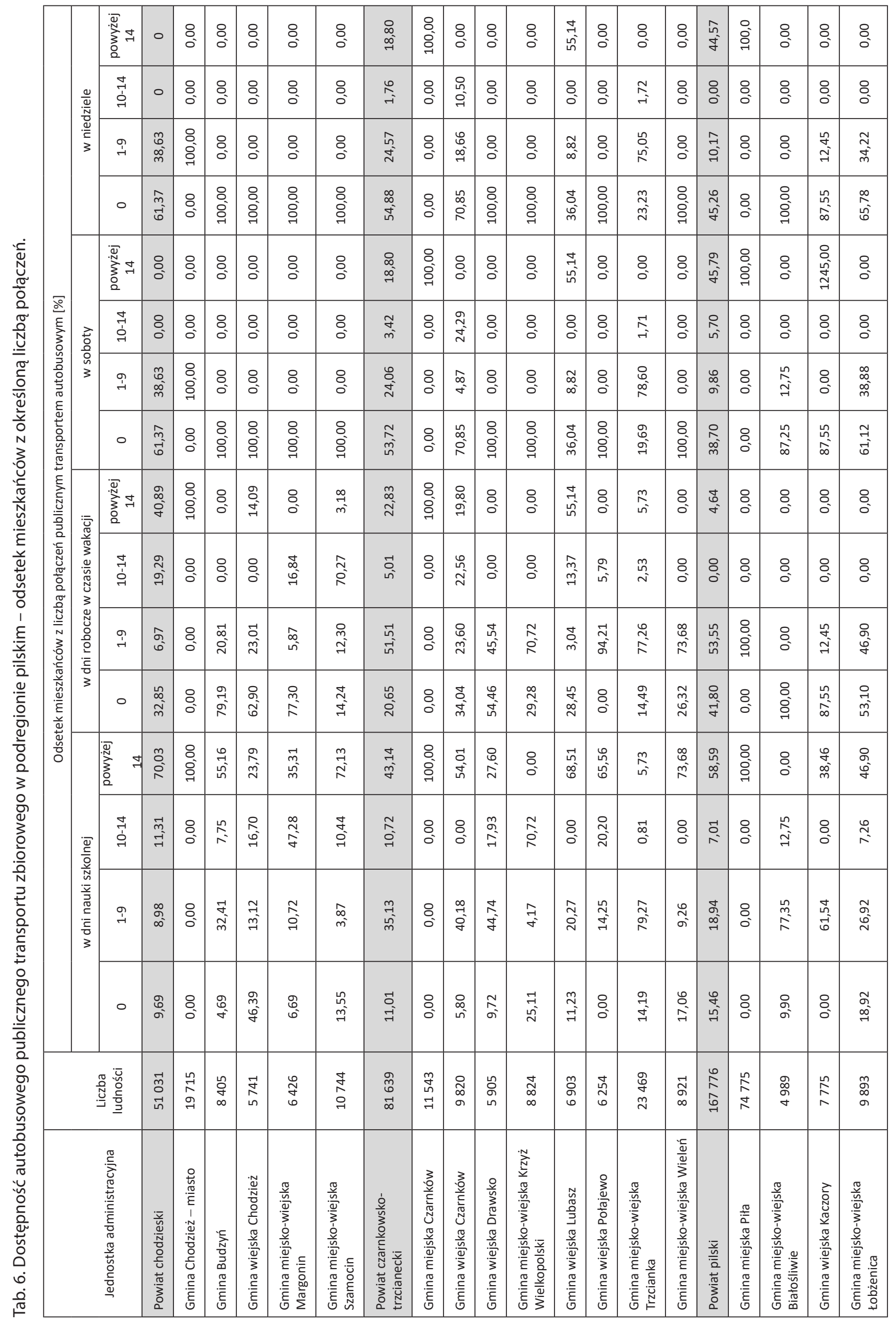




\begin{tabular}{|c|c|c|c|c|c|c|c|c|c|c|c|c|c|c|c|c|c|c|c|c|c|}
\hline$\stackrel{8}{\circ}$ & : & 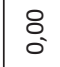 & : & : & : & : & 8 & 8 & $\stackrel{8}{8}$ & 8 & $\begin{array}{l}8 \\
0 \\
0\end{array}$ & $\begin{array}{l}\infty \\
\stackrel{-}{\infty} \\
\rightarrow\end{array}$ & $\stackrel{8}{\circ}$ & : & $\stackrel{8}{\circ}$ & 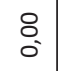 & $\stackrel{\infty}{\stackrel{\infty}{N}}$ & : & $\begin{array}{l}\text { Fे } \\
\text { f }\end{array}$ & : & $\begin{array}{l}\text { Rे } \\
\text { i }\end{array}$ \\
\hline$\stackrel{0}{0}$ & \&. & o. & : & : & 8 & 8 & 8 & 8 & $\begin{array}{l}8 \\
0 \\
0\end{array}$ & 8 & $\begin{array}{l}8 \\
0 \\
0\end{array}$ & $\begin{array}{l}J \\
0\end{array}$ & $\stackrel{8}{\circ}$ & $\stackrel{8}{\circ}$ & $\stackrel{8}{\circ}$ & $\begin{array}{l}8 \\
0 \\
0\end{array}$ & $\underset{\sim}{\tilde{N}}$ & 8 & \& & 8 & 웅 \\
\hline 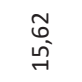 & : & $\begin{array}{l}\tilde{\sigma} \\
\tilde{f}\end{array}$ & 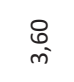 & \begin{tabular}{l}
$\infty$ \\
$\stackrel{\infty}{\sim}$ \\
\multirow{\sim}{*}{}
\end{tabular} & : & : & $\stackrel{\circ}{\circ}$ & : & $\stackrel{8}{\circ}$ & 8 & $\stackrel{8}{\circ}$ & $\begin{array}{l}\stackrel{2}{2} \\
\overbrace{}^{\infty} \\
\sim\end{array}$ & $\stackrel{8}{\circ}$ & $\stackrel{8}{\circ}$ & $\stackrel{8}{\circ}$ & $\stackrel{8}{\circ}$ & $\stackrel{0}{\circ}$ & 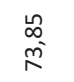 & 8 & \begin{tabular}{l}
$\underset{\infty}{\infty}$ \\
\multirow{f}{f}{}
\end{tabular} & 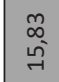 \\
\hline 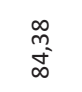 & $\begin{array}{l}8 \\
8 \\
0 \\
0\end{array}$ & $\begin{array}{l}\tilde{N} \\
\sim \\
\sim\end{array}$ & $\begin{array}{l}\text { g্ } \\
\text { ه̆ }\end{array}$ & $\underset{\substack{\tilde{N}\\
}}{ }$ & $\begin{array}{l}8 \\
8 \\
0 \\
0\end{array}$ & $\begin{array}{l}8 \\
\text { : } \\
\text { - }\end{array}$ & $\begin{array}{l}\text { ه } \\
\text { ᄋ् }\end{array}$ & $\begin{array}{l}\text { ه } \\
\text { ò }\end{array}$ & $\begin{array}{l}8 \\
\stackrel{0}{0} \\
0\end{array}$ & $\begin{array}{l}8 \\
0 \\
0 \\
0\end{array}$ & $\begin{array}{l}8 \\
\stackrel{.}{0} \\
\stackrel{-}{*}\end{array}$ & $\begin{array}{l}\stackrel{n}{n} \\
\text { g }\end{array}$ & 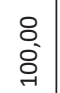 & 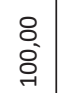 & $\begin{array}{l}8 \\
\stackrel{0}{0} \\
\circ\end{array}$ & $\begin{array}{l}8 \\
\stackrel{0}{0} \\
\stackrel{-}{0}\end{array}$ & $\begin{array}{l}\text { ते } \\
\text { S̃ }\end{array}$ & $\begin{array}{l}\text { ? } \\
\text { ه్ }\end{array}$ & $\begin{array}{l}\infty \\
\infty \\
\sim \\
\infty \\
\infty \\
\infty\end{array}$ & 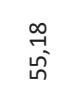 & $\begin{array}{l}\text { જે } \\
\text { స్ }\end{array}$ \\
\hline $\begin{array}{l}\text { ô } \\
\text { ș }\end{array}$ & 8 & 苂 & : & 8 & 8 & 8 & 8 & : & $\begin{array}{l}8 \\
0 \\
0\end{array}$ & 8 & $\begin{array}{l}8 \\
0 \\
0\end{array}$ & $\underset{n}{\stackrel{N}{N}}$ & $\stackrel{8}{\circ}$ & : & : & $\begin{array}{l}8 \\
0\end{array}$ & 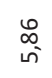 & : & $\begin{array}{l}\text { Fे } \\
\text { J }\end{array}$ & : & $\underset{\sim}{m}$ \\
\hline$\stackrel{8}{\circ}$ & $\underset{\rightarrow}{A}$ & 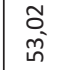 & 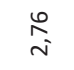 & : & : & : & : & : & $\stackrel{8}{\circ}$ & 8 & $\begin{array}{l}8 \\
: \\
\circ\end{array}$ & $\stackrel{\circ}{\circ}$ & $\stackrel{\circ}{\circ}$ & $\stackrel{\circ}{\circ}$ & $\stackrel{0}{0}$ & $\stackrel{8}{\circ}$ & : & o & : & : & $\stackrel{\vec{\infty}}{\overrightarrow{0}}$ \\
\hline 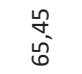 & $\begin{array}{l}\infty \\
\infty \\
\mathcal{N}\end{array}$ & $\begin{array}{l}\text { L } \\
\text { ผn. }\end{array}$ & $\underset{\leftarrow}{\stackrel{\leftrightarrow}{*}}$ & 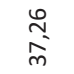 & : & : & : & : & $\stackrel{8}{\circ}$ & 8 & $\stackrel{8}{8}$ & $\begin{array}{l}\stackrel{2}{2} \\
\infty^{\infty}\end{array}$ & $\stackrel{8}{\circ}$ & $\stackrel{8}{\circ}$ & $\stackrel{\circ}{\circ}$ & $\stackrel{8}{\circ}$ & : & $\begin{array}{l}\infty \\
\stackrel{N}{N}\end{array}$ & $\stackrel{8}{\circ}$ & 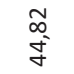 & นึ \\
\hline 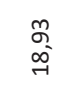 & $\begin{array}{l}\sqrt{n} \\
\stackrel{5}{n}\end{array}$ & ન્ & 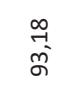 & $\begin{array}{l}\text { J } \\
\text { S }\end{array}$ & $\begin{array}{l}8 \\
8 \\
0\end{array}$ & $\begin{array}{l}8 \\
\text { ¿ } \\
\text { - }\end{array}$ & $\begin{array}{l}\text { : } \\
\text { ○े }\end{array}$ & $\begin{array}{l}\text { ه } \\
\text { o }\end{array}$ & $\begin{array}{l}8 \\
\stackrel{-}{0} \\
0\end{array}$ & $\begin{array}{l}8 \\
0 \\
0 \\
0\end{array}$ & $\begin{array}{l}8 \\
\stackrel{-}{0} \\
0\end{array}$ & $\begin{array}{l}\text { 岇 } \\
\text { న }\end{array}$ & $\begin{array}{l}8 \\
8 \\
0 \\
0\end{array}$ & $\begin{array}{l}8 \\
\stackrel{0}{0} \\
0\end{array}$ & $\begin{array}{l}8 \\
\stackrel{0}{0} \\
0\end{array}$ & $\begin{array}{l}8 \\
8 \\
0 \\
0\end{array}$ & \begin{tabular}{l}
$\stackrel{J}{*}$ \\
\multirow{\sigma}{*}{}
\end{tabular} & $\begin{array}{l}\text { n } \\
\text { d్ }\end{array}$ & $\begin{array}{l}\infty \\
\infty \\
\infty \\
\infty \\
\infty\end{array}$ & 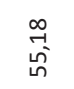 & $\begin{array}{c}\tilde{z} \\
\text { s. }\end{array}$ \\
\hline$:$ & 8 & $\begin{array}{l}\stackrel{R}{\sigma} \\
\dot{f}\end{array}$ & : & $\stackrel{8}{0}$ & : & : & : & : & $\stackrel{8}{\circ}$ & 8 & $\begin{array}{l}8 \\
0 \\
0\end{array}$ & 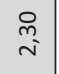 & : & : & : & : & $\begin{array}{l}\infty \\
\infty \\
\aleph^{\circ}\end{array}$ & 8 & 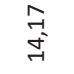 & 8 & $\begin{array}{l}\approx \\
\exists \\
\exists\end{array}$ \\
\hline : & : & : & : & : & : & : & : & : & $\begin{array}{l}8 \\
0\end{array}$ & $\begin{array}{l}8 \\
0\end{array}$ & $\begin{array}{l}8 \\
0\end{array}$ & $\begin{array}{l}\tilde{N} \\
\tilde{r} \\
\vec{v}\end{array}$ & : & 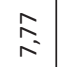 & : & $\begin{array}{l}8 \\
0\end{array}$ & : & 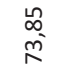 & : & : & $\begin{array}{l}\tilde{n} \\
\tilde{\omega}\end{array}$ \\
\hline $\begin{array}{l}\text { ने } \\
\text { d }\end{array}$ & $\underset{\leftarrow}{\&}$ & $\underset{\infty}{\stackrel{0}{0}}$ & ન્ & $\begin{array}{l}\stackrel{2}{N} \\
\stackrel{n}{m}\end{array}$ & $\begin{array}{l}\vec{f} \\
\dot{g}\end{array}$ & $\begin{array}{l}\mathscr{8} \\
\stackrel{8}{6}\end{array}$ & 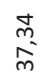 & જ. & $\begin{array}{l}8 \\
0 \\
0\end{array}$ & $\begin{array}{l}8 \\
0 \\
0\end{array}$ & $\underset{m}{\tilde{m}}$ & $\begin{array}{l}\stackrel{\infty}{\check{\sim}} \\
\stackrel{f}{A}\end{array}$ & 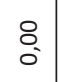 & $\stackrel{\infty}{\stackrel{\infty}{F}}$ & $\begin{array}{c}0 \\
\stackrel{0}{\sim} \\
\end{array}$ & 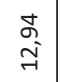 & $\begin{array}{l}0 \\
0 \\
0\end{array}$ & : & ờ & $\begin{array}{c}\widetilde{\infty} \\
\underset{f}{f}\end{array}$ & $\begin{array}{l}0 \\
0 \\
0 \\
0\end{array}$ \\
\hline 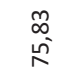 & $\begin{array}{l}9 \\
\text { 9 } \\
\text { s. }\end{array}$ & $\begin{array}{l}f \\
g \\
g\end{array}$ & 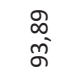 & 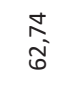 & $\begin{array}{l}\text { مू. } \\
\text { హิ }\end{array}$ & 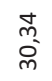 & 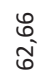 & $\begin{array}{l}\overrightarrow{5} \\
\text { gे }\end{array}$ & \begin{tabular}{|l|}
8 \\
0 \\
0 \\
0
\end{tabular} & \begin{tabular}{|l|}
8 \\
0 \\
0 \\
0
\end{tabular} & $\begin{array}{l}\hat{n} \\
\hat{s} \\
\Omega\end{array}$ & $\begin{array}{l}\text { \& } \\
\text { के } \\
6\end{array}$ & $\begin{array}{l}8 \\
8 \\
0 \\
0\end{array}$ & $\begin{array}{l}\text { f } \\
\stackrel{5}{\circ} \\
n\end{array}$ & $\begin{array}{l}0 \\
\stackrel{0}{0} \\
\infty \\
\infty\end{array}$ & $\begin{array}{l}0 \\
\stackrel{-}{-1} \\
\infty\end{array}$ & 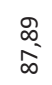 & $\begin{array}{l}\text { ñ } \\
\text { s. }\end{array}$ & $\begin{array}{l}\stackrel{2}{0} \\
\text { s. }\end{array}$ & 忿 & 离 \\
\hline$\underset{\text { I }}{\text { ने }}$ & $\underset{G}{f}$ & $\begin{array}{l}8 \\
0 \\
0 \\
0\end{array}$ & 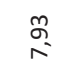 & $\begin{array}{l}\text { ने } \\
\text { न }\end{array}$ & $\stackrel{\infty}{\stackrel{\infty}{=}}$ & 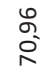 & 8 & 8 & 8 & 8 & $\begin{array}{l}8 \\
0 \\
0\end{array}$ & $\begin{array}{l}\tilde{N} \\
\text { w్ }\end{array}$ & : & $\stackrel{i}{i}$ & : & $\begin{array}{l}8 \\
0 \\
0\end{array}$ & 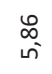 & $\begin{array}{l}\infty^{\infty} \\
\stackrel{N}{N}\end{array}$ & $\underset{f}{\hat{f}}$ & 8 & $\begin{array}{l}\hat{\infty} \\
0 \\
g \\
g\end{array}$ \\
\hline$\underset{g}{g}$ & 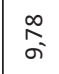 & 8 & $\begin{array}{l}\vec{\Delta} \\
\stackrel{\vec{m}}{-}\end{array}$ & $\begin{array}{l}\text { 员 } \\
\text { o }\end{array}$ & $\underset{m}{\Delta}$ & 8 & 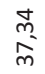 & 8 & 8 & 8 & $\begin{array}{l}8 \\
0 \\
0\end{array}$ & $\underset{\infty}{9}$ & $\begin{array}{l}8 \\
0 \\
0\end{array}$ & $\underset{\sim}{\stackrel{\sim}{\sim}}$ & 8 & 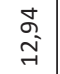 & 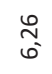 & 8 & 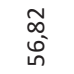 & 8 & $\stackrel{0}{\stackrel{2}{2}}$ \\
\hline$\underset{\text { î }}{\text { in }}$ & $\begin{array}{c}5 \\
0 \\
0\end{array}$ & 孕 & $\stackrel{\infty}{\stackrel{\infty}{i}}$ & 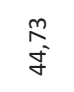 & $\stackrel{\vec{N}}{\stackrel{\sim}{\sim}}$ & $\begin{array}{l}\hat{a} \\
\text { s. } \\
\text { - }\end{array}$ & $\underset{\substack{m \\
\sim}}{\sim}$ & 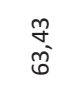 & $\begin{array}{l}0 \\
\text { in } \\
\text { in }\end{array}$ & $\underset{f}{\stackrel{f}{-}}$ & $\begin{array}{l}\text { 员 } \\
\text { s. } \\
0\end{array}$ & $\begin{array}{l}\stackrel{0}{1} \\
\stackrel{1}{n}\end{array}$ & $\begin{array}{l}8 \\
8 \\
0 \\
0\end{array}$ & 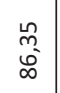 & $\stackrel{\circ}{\stackrel{\circ}{N}}$ & 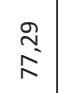 & $\begin{array}{l}\stackrel{0}{2} \\
\stackrel{n}{*}\end{array}$ & 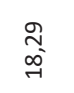 & $\stackrel{t}{\stackrel{A}{A}}$ & $\begin{array}{l}\stackrel{n^{\prime}}{\sigma} \\
\text { g. }\end{array}$ & 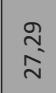 \\
\hline 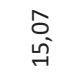 & $\mid \begin{array}{l}\hat{K} \\
\text { t. }\end{array}$ & \begin{tabular}{|l}
$\vec{m}$ \\
$\tilde{m}$
\end{tabular} & $\begin{array}{l}\text { 总 } \\
\text { in }\end{array}$ & $\stackrel{8}{\circ}$ & $\begin{array}{l}\hat{\vec{m}} \\
\vec{m}\end{array}$ & $\begin{array}{l}\mathscr{0} \\
\tilde{y}\end{array}$ & 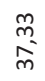 & $\begin{array}{l}\hat{n} \\
\text { n్ } \\
\text { ñ }\end{array}$ & $\mid \begin{array}{l}m \\
\tilde{y} \\
\tilde{y}\end{array}$ & $\mid \begin{array}{c}n \\
\stackrel{n}{\alpha} \\
\infty\end{array}$ & $\begin{array}{c}\stackrel{0}{0} \\
\stackrel{m}{m}\end{array}$ & 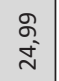 & : & 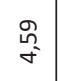 & $\begin{array}{l}0 \\
0 \\
0 \\
\infty \\
\infty\end{array}$ & $\begin{array}{l}\hat{\sigma} \\
\sigma\end{array}$ & 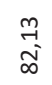 & $\stackrel{\infty}{\sim}$ & $\stackrel{\tilde{I}}{\vec{I}}$ & 导 & $\begin{array}{l}\infty \\
\infty \\
\infty \\
\infty\end{array}$ \\
\hline$\underset{\sim}{\stackrel{\sim}{0}}$ & $\begin{array}{l}\hat{y} \\
\infty\end{array}$ & $\begin{array}{l}0 \\
0 \\
0 \\
0 \\
\end{array}$ & $\begin{array}{l}\vec{G} \\
\text { D } \\
\stackrel{\sim}{\sim}\end{array}$ & 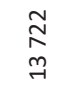 & $\begin{array}{l}8 \\
8 \\
0 \\
0\end{array}$ & $\begin{array}{l}0 \\
\stackrel{n}{n} \\
i \\
\tilde{m}\end{array}$ & $\begin{array}{l}\text { Uే } \\
\text { in }\end{array}$ & $\begin{array}{l}\underset{\infty}{\sim} \\
\stackrel{1}{n} \\
\infty\end{array}$ & 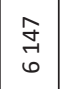 & $\begin{array}{c}\hat{\aleph} \\
\infty \\
\infty\end{array}$ & $\begin{array}{l}\stackrel{0}{7} \\
\stackrel{m}{m}\end{array}$ & $\begin{array}{l}\stackrel{1}{N} \\
\stackrel{2}{N}\end{array}$ & 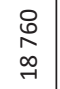 & $\begin{array}{l}\overrightarrow{0} \\
\text { in }\end{array}$ & 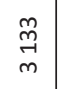 & $\begin{array}{l}\tilde{N} \\
\sigma \\
\sigma\end{array}$ & 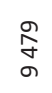 & $\begin{array}{l}\vec{S} \\
\vec{A}\end{array}$ & $\stackrel{-1}{n}$ & \begin{tabular}{l}
\multirow{J}{J}{} \\
$\sigma$
\end{tabular} & 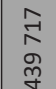 \\
\hline 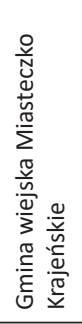 & 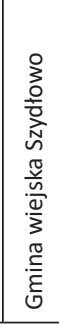 & 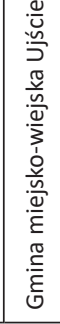 & 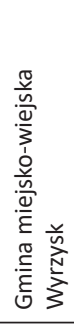 & 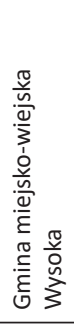 & 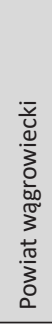 & 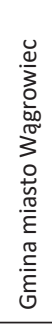 & 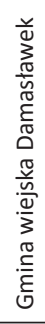 & 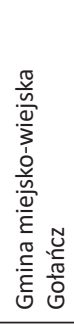 & 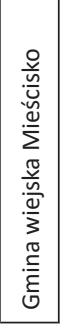 & 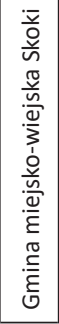 & 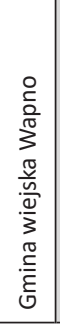 & 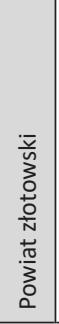 & 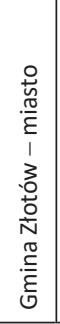 & 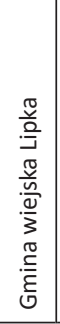 & 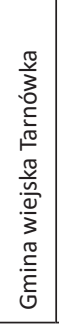 & 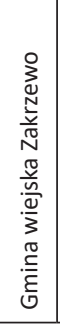 & 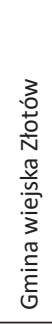 & 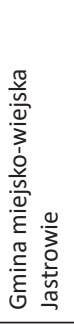 & 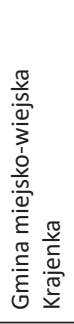 & 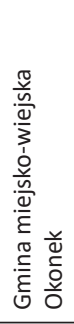 & 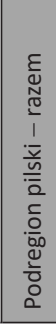 \\
\hline
\end{tabular}




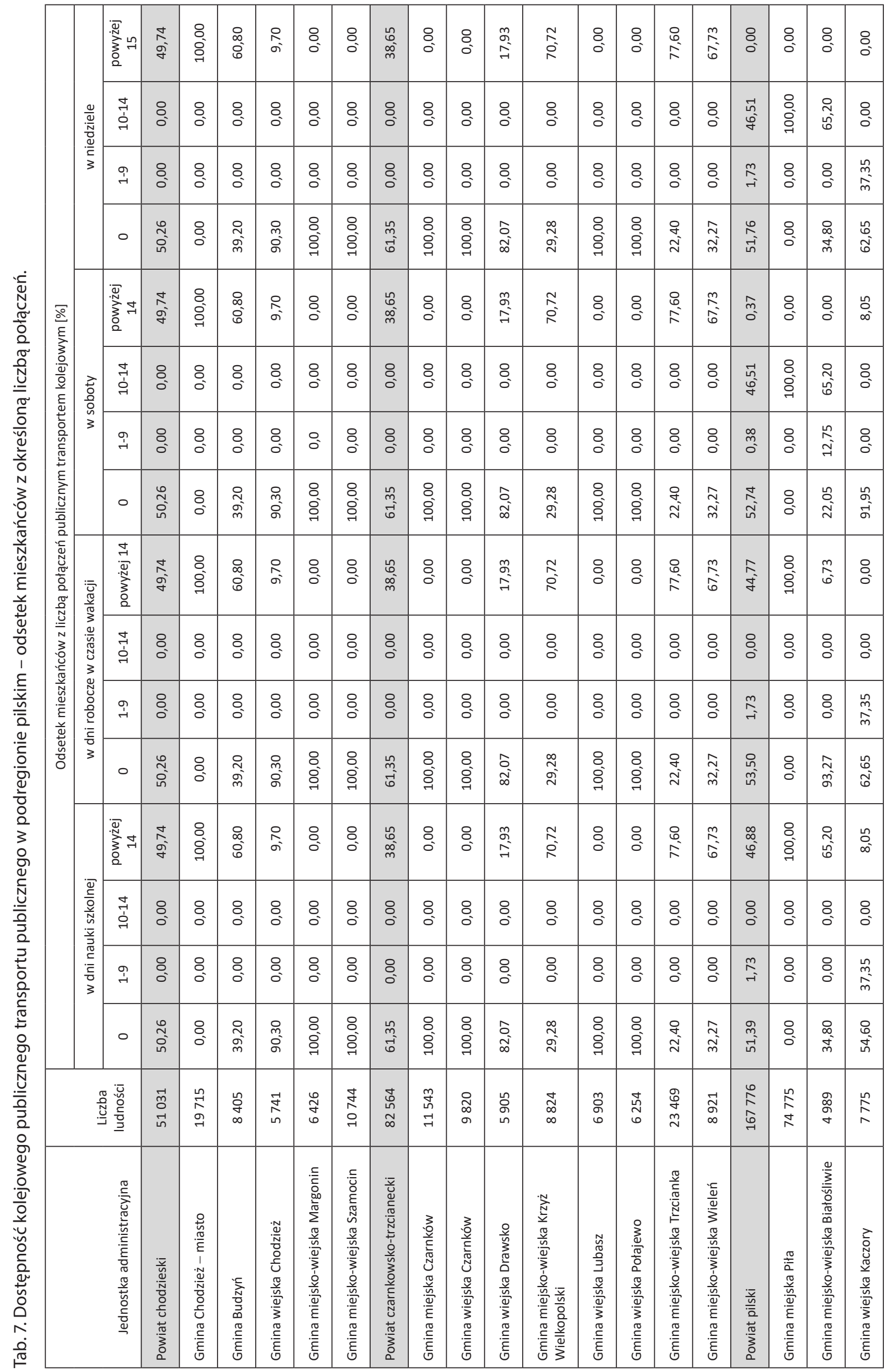




\begin{tabular}{|c|c|c|c|c|c|c|c|c|c|c|c|c|c|c|c|c|c|c|c|c|c|c|}
\hline 8 & 8 & : & 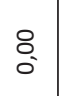 & $:$ & 8 & 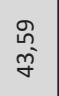 & $\begin{array}{l}\stackrel{0}{1} \\
\stackrel{\Sigma}{\Sigma}\end{array}$ & : & : & $\begin{array}{l}8 \\
0 \\
0\end{array}$ & $\begin{array}{l}\stackrel{\leftrightarrow}{\circ} \\
\stackrel{\sigma}{*}\end{array}$ & $\begin{array}{l}8 \\
0 \\
0\end{array}$ & $\begin{array}{l}\stackrel{\infty}{\infty} \\
\stackrel{\infty}{A}\end{array}$ & $\begin{array}{l}8 \\
0 \\
0\end{array}$ & : & $\begin{array}{l}8 \\
0 \\
0\end{array}$ & 8 & 8 & 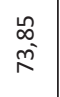 & $\begin{array}{l}0 \\
\stackrel{0}{0} \\
i n\end{array}$ & 8 & 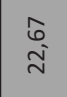 \\
\hline ठ0 & : & : & $\stackrel{8}{\circ}$ & : & : & 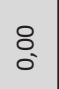 & $\begin{array}{l}8 \\
\circ \\
\circ\end{array}$ & : & : & $\begin{array}{l}8 \\
0\end{array}$ & 8 & : & $\begin{array}{l}\vec{m} \\
\hat{\omega}^{-}\end{array}$ & $\begin{array}{l}8 \\
0 \\
0 \\
0\end{array}$ & : & $\begin{array}{l}\stackrel{0}{n} \\
m_{n-1}\end{array}$ & 8 & 8 & 8 & $\begin{array}{l}\stackrel{n}{二} \\
\vec{\exists}\end{array}$ & $\begin{array}{l}m \\
\stackrel{2}{0} \\
0\end{array}$ & $\underset{\substack{0 \\
\sim}}{\sim}$ \\
\hline 8 & : & : & $\begin{array}{l}8 \\
0 \\
0\end{array}$ & : & \& & ๙્. & $\underset{\sim}{\stackrel{\sim}{\sim}}$ & : & \begin{tabular}{c}
\multirow{N}{N}{} \\
S.
\end{tabular} & $\stackrel{8}{\circ}$ & : & : & $\underset{i}{\stackrel{t}{N}}$ & $\stackrel{8}{0}$ & : & $\stackrel{8}{0}$ & $\begin{array}{l}8 \\
\text { o } \\
\text { je }\end{array}$ & 8 & $\stackrel{8}{8}$ & 8 & 8 & $\stackrel{\widetilde{N}}{i}$ \\
\hline : & $\begin{array}{l}8 \\
\text { ○े } \\
\text { - }\end{array}$ & $\begin{array}{l}8 \\
\text { ò } \\
\text { - }\end{array}$ & $\begin{array}{l}8 \\
\stackrel{-}{\circ} \\
\text { - }\end{array}$ & 离 & $\begin{array}{l}8 \\
\stackrel{0}{0} \\
0\end{array}$ & $\begin{array}{l}\text { g } \\
\text { o } \\
\text { in }\end{array}$ & 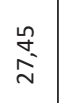 & $\begin{array}{l}8 \\
\text { ò } \\
\text { - }\end{array}$ & 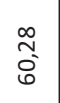 & : & 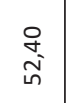 & $\begin{array}{l}8 \\
\text { ò } \\
\text { a }\end{array}$ & 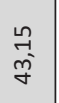 & $\stackrel{8}{\circ}$ & $\begin{array}{l}8 \\
\stackrel{0}{\circ} \\
\text { a }\end{array}$ & $\begin{array}{l}\text { on } \\
\text { s. } \\
\infty\end{array}$ & 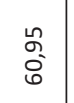 & $\begin{array}{l}8 \\
8 \\
0 \\
0\end{array}$ & 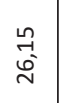 & 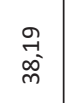 & $\begin{array}{l}\hat{0} \\
\text { ì } \\
\text { no }\end{array}$ & $\begin{array}{l}\vec{\infty} \\
\vec{n}\end{array}$ \\
\hline 8 & : & : & $\begin{array}{l}8 \\
0 \\
0\end{array}$ & : & : & 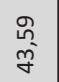 & $\begin{array}{l}\stackrel{2}{2} \\
\stackrel{2}{n}\end{array}$ & : & $\stackrel{8}{8}$ & $\stackrel{8}{\circ}$ & 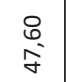 & : & $\begin{array}{l}\stackrel{\infty}{0} \\
\stackrel{\sim}{二}\end{array}$ & $\stackrel{8}{8}$ & : & $\stackrel{8}{0}$ & 8 & 8 & $\begin{array}{l}\stackrel{\infty}{\infty} \\
\substack{\infty \\
\sim}\end{array}$ & $\begin{array}{l}8 \\
: \\
0 \\
n\end{array}$ & 8 & $\begin{array}{l}\overrightarrow{0} \\
\vec{N}\end{array}$ \\
\hline 8 & o & : & 8 & $:$ & : & 8 & 8 & : & : & $:$ & $\begin{array}{l}8 \\
0\end{array}$ & 8 & \begin{tabular}{l}
$m$ \\
\multirow{d}{*}{} \\
0 \\
$m$
\end{tabular} & $\begin{array}{l}8 \\
0 \\
0 \\
\end{array}$ & 8 & $\begin{array}{l}\stackrel{0}{n} \\
\stackrel{n}{n} \\
\text { t. }\end{array}$ & $\underset{\sim}{\stackrel{\leftrightarrow}{\circ}}$ & 8 & 8 & $\underset{f}{\stackrel{n}{ت}}$ & $\begin{array}{l}m \\
0 \\
0 \\
0\end{array}$ & $\underset{\substack{\tilde{N} \\
\widetilde{\sim}}}{\sim}$ \\
\hline 8 & : & : & $:$ & $\stackrel{0}{\circ}$ & : & $\begin{array}{l}\tilde{\tilde{z}} \\
\text { in }\end{array}$ & $\underset{\sim}{\stackrel{\sim}{\sim}}$ & : & 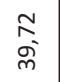 & $\stackrel{0}{0}$ & 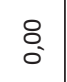 & $\stackrel{8}{\circ}$ & $\begin{array}{l}\tilde{0} \\
i\end{array}$ & 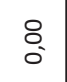 & : & $\begin{array}{l}8 \\
0 \\
0\end{array}$ & $\begin{array}{l}q \\
i \\
i \\
m\end{array}$ & : & 8 & $\begin{array}{l}8 \\
0 \\
0\end{array}$ & 8 & $\stackrel{g}{\rightarrow}$ \\
\hline $\begin{array}{l}8 \\
\text { वे } \\
\end{array}$ & $\begin{array}{l}8 \\
\text { : } \\
\text { - }\end{array}$ & $\begin{array}{l}\stackrel{8}{0} \\
\text { ○े }\end{array}$ & $\begin{array}{l}8 \\
\stackrel{8}{0} \\
\text { - }\end{array}$ & $\begin{array}{l}\text { : } \\
\text { : } \\
\text { - }\end{array}$ & $\begin{array}{l}\text { : } \\
\text { ○े }\end{array}$ & $\begin{array}{l}\text { g) } \\
\text { in }\end{array}$ & 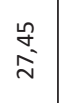 & $\begin{array}{l}\text { : } \\
\text { : } \\
\text { - }\end{array}$ & $\begin{array}{l}\infty \\
\stackrel{\sim}{0} \\
\stackrel{0}{0}\end{array}$ & $\begin{array}{l}8 \\
: \\
: \\
\stackrel{-}{1}\end{array}$ & $\underset{\substack{\mathfrak{j} \\
\mathfrak{n}}}{ }$ & $\begin{array}{l}8 \\
\text { o } \\
\text { - }\end{array}$ & 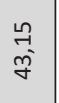 & : & $\begin{array}{l}\stackrel{8}{\circ} \\
\stackrel{0}{0}\end{array}$ & $\begin{array}{l}0 \\
\substack{n \\
\text { s. } \\
\infty}\end{array}$ & $\begin{array}{l}\text { ñ } \\
\stackrel{\Delta}{0} \\
0\end{array}$ & $\begin{array}{l}8 \\
8 \\
0 \\
0\end{array}$ & $\begin{array}{l}n \\
\stackrel{n}{-} \\
\stackrel{d}{n}\end{array}$ & 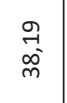 & $\begin{array}{l}\hat{a} \\
\text { ò } \\
\text { no }\end{array}$ & $\begin{array}{l}\text { 文 } \\
\underset{\text { ñ }}{ }\end{array}$ \\
\hline 8 & 8 & 8 & 8 & $:$ & : & 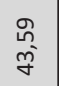 & $\begin{array}{l}\stackrel{2}{2} \\
\stackrel{2}{n}\end{array}$ & : & 8 & $:$ & $\begin{array}{l}\stackrel{\leftrightarrow}{\sim} \\
\stackrel{\sigma}{*}\end{array}$ & $\stackrel{8}{\circ}$ & 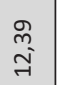 & $\begin{array}{l}8 \\
0 \\
0\end{array}$ & : & $\begin{array}{l}8 \\
0\end{array}$ & $\begin{array}{l}8 \\
0\end{array}$ & 8 & $\begin{array}{l}\stackrel{\infty}{\infty} \\
\substack{\infty \\
N}\end{array}$ & $\begin{array}{l}8 \\
0 \\
0\end{array}$ & $\begin{array}{l}8 \\
0 \\
0\end{array}$ & 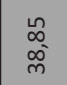 \\
\hline 8 & $\begin{array}{l}8 \\
0 \\
0\end{array}$ & $\begin{array}{l}8 \\
0 \\
0\end{array}$ & $\begin{array}{l}8 \\
0 \\
0\end{array}$ & : & $\begin{array}{l}8 \\
0 \\
0\end{array}$ & $\begin{array}{l}8 \\
0 \\
0\end{array}$ & $\begin{array}{l}8 \\
0 \\
0\end{array}$ & o & $\begin{array}{l}8 \\
0 \\
0\end{array}$ & : & $\begin{array}{l}8 \\
0\end{array}$ & $\begin{array}{l}8 \\
0 \\
0\end{array}$ & $\begin{array}{l} \pm \\
0 \\
\vec{\sigma} \\
\vec{\sigma}\end{array}$ & $\begin{array}{l}8 \\
: \\
8 \\
\end{array}$ & : & 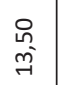 & $\underset{\sim}{\stackrel{\leftrightarrow}{\rightarrow}}$ & $\begin{array}{l}8 \\
0 \\
0\end{array}$ & $\stackrel{8}{\circ}$ & $\begin{array}{l}\overrightarrow{0} \\
\overrightarrow{0} \\
\overrightarrow{0}\end{array}$ & 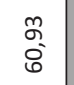 & $\begin{array}{l}\hat{6} \\
\mathfrak{6}^{\circ}\end{array}$ \\
\hline 8 & 8 & 8 & 8 & : & $\stackrel{8}{0}$ & $\begin{array}{l}\tilde{\tilde{n}} \\
\text { in }\end{array}$ & $\underset{\sim}{\stackrel{\sim}{\sim}}$ & : & 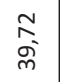 & : & $\begin{array}{l}8 \\
0 \\
0\end{array}$ & $\stackrel{8}{\circ}$ & $\begin{array}{l}\tilde{O} \\
i\end{array}$ & 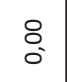 & : & $\begin{array}{l}8 \\
0 \\
0\end{array}$ & 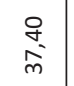 & $\stackrel{8}{\circ}$ & $\stackrel{8}{8}$ & $\stackrel{8}{\circ}$ & $\stackrel{8}{\circ}$ & $\stackrel{8}{i}$ \\
\hline $\begin{array}{l}\text { : } \\
\text { gे }\end{array}$ & $\begin{array}{l}8 \\
\text { : } \\
\text { - }\end{array}$ & $\begin{array}{l}\stackrel{8}{0} \\
\text { ○े }\end{array}$ & $\begin{array}{l}8 \\
: \\
\text { o. }\end{array}$ & $\begin{array}{l}\stackrel{8}{0} \\
\stackrel{-}{\circ}\end{array}$ & $\begin{array}{l}8 \\
\stackrel{0}{0} \\
\text { - }\end{array}$ & $\begin{array}{l}\text { g) } \\
\text { in }\end{array}$ & 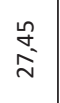 & $\begin{array}{l}\text { : } \\
\text { : } \\
0\end{array}$ & $\begin{array}{l}\infty \\
\stackrel{0}{0} \\
\stackrel{0}{0}\end{array}$ & $\begin{array}{l}8 \\
\text { Oें } \\
\text { - }\end{array}$ & 吕 & $\begin{array}{l}8 \\
\text { o } \\
\text { - }\end{array}$ & $\underset{\substack{n \\
\tilde{g}}}{\stackrel{n}{n}}$ & $\begin{array}{l}8 \\
0 \\
0\end{array}$ & $\begin{array}{l}\stackrel{8}{0} \\
\text { o }\end{array}$ & $\begin{array}{l}0 \\
\text { h్ } \\
\text { o. } \\
\infty\end{array}$ & $\begin{array}{l}\text { ñ } \\
\text { Oे. } \\
0\end{array}$ & $\begin{array}{l}8 \\
8 \\
0 \\
0\end{array}$ & 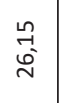 & 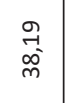 & 家 & ๙ิ \\
\hline 8 & 8 & 8 & 8 & : & : & 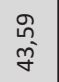 & 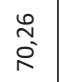 & $\stackrel{8}{0}$ & 8 & $\stackrel{8}{0}$ & $\begin{array}{l}\stackrel{0}{\circ} \\
\stackrel{\sigma}{\sigma}\end{array}$ & 8 & 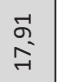 & 8 & : & $\stackrel{8}{0}$ & $\underset{\sim}{\stackrel{\leftrightarrow}{-}}$ & 8 & $\begin{array}{l}\stackrel{\infty}{\infty} \\
\stackrel{\infty}{\sim} \\
\sim\end{array}$ & $\begin{array}{l}: \\
: \\
0 \\
i n\end{array}$ & 8 & 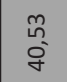 \\
\hline 8 & : & $\stackrel{8}{\circ}$ & $\begin{array}{l}8 \\
0 \\
0\end{array}$ & : & : & 8 & 8 & : & : & $\begin{array}{l}8 \\
0 \\
0\end{array}$ & $\begin{array}{l}8 \\
0\end{array}$ & : & $\begin{array}{l}\vec{m} \\
\hat{m}^{-}\end{array}$ & $\begin{array}{l}8 \\
0 \\
0 \\
0\end{array}$ & $\stackrel{8}{\circ}$ & $\begin{array}{l}\stackrel{0}{0} \\
\underset{y}{m}\end{array}$ & 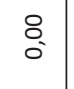 & 8 & $\begin{array}{l}8 \\
0 \\
0\end{array}$ & $\underset{\stackrel{n}{7}}{\vec{f}}$ & $\begin{array}{l}m \\
\stackrel{n}{ } \\
\dot{0}\end{array}$ & ๙̊. \\
\hline 8 & : & : & $\stackrel{8}{0}$ & : & $\stackrel{8}{0}$ & స్ & 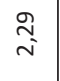 & : & 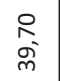 & : & $\begin{array}{l}8 \\
0\end{array}$ & : & 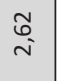 & $\begin{array}{l}8 \\
0 \\
0\end{array}$ & : & $\stackrel{0}{0}$ & $\begin{array}{l}\stackrel{g}{a} \\
\stackrel{m}{c}\end{array}$ & : & $\stackrel{8}{8}$ & : & 8 & $\stackrel{\text { i }}{i}$ \\
\hline 8 & $\begin{array}{l}\text { o } \\
\text { ò }\end{array}$ & $\begin{array}{l}\text { : } \\
\text { ○े }\end{array}$ & $\begin{array}{l}\stackrel{8}{0} \\
\text { oे }\end{array}$ & $\begin{array}{l}8 \\
\text { : } \\
\text { aे }\end{array}$ & 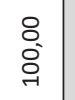 & $\begin{array}{l}\text { g) } \\
\text { in } \\
\text { in }\end{array}$ & 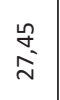 & $\begin{array}{l}\text { : } \\
\text { : } \\
\text { - }\end{array}$ & $\begin{array}{l}\stackrel{\infty}{\widetilde{c}} \\
\stackrel{\Xi}{0}\end{array}$ & $\begin{array}{l}\text { : } \\
\text { ò }\end{array}$ & $\begin{array}{l}q \\
i \\
i n\end{array}$ & $\begin{array}{l}8 \\
\stackrel{0}{0} \\
\text { a }\end{array}$ & $\stackrel{\stackrel{n}{q}}{\stackrel{\sim}{\gamma}}$ & 8 & $\begin{array}{l}\stackrel{8}{0} \\
\text { ○े }\end{array}$ & 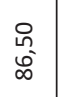 & $\begin{array}{l}\text { n. } \\
\text { ô } \\
0\end{array}$ & $\begin{array}{l}8 \\
\stackrel{0}{0} \\
0\end{array}$ & 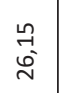 & 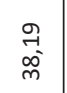 & $\begin{array}{l}\hat{0} \\
\dot{m} \\
\dot{m}\end{array}$ & $\begin{array}{l}\hat{6} \\
\text { in }\end{array}$ \\
\hline ñ & 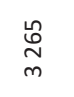 & $\stackrel{\hat{q}}{\infty}$ & $\begin{array}{l}\stackrel{0}{0} \\
\stackrel{0}{c} \\
\stackrel{\leftrightarrow}{1}\end{array}$ & $\begin{array}{l}\underset{d}{0} \\
\text { D. } \\
\text { | }\end{array}$ & 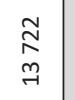 & $\begin{array}{l}8 \\
8 \\
0\end{array}$ & 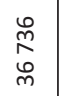 & $\begin{array}{l}\stackrel{0}{0} \\
\text { in }\end{array}$ & $\begin{array}{l}\infty \\
\stackrel{\sim}{\sim} \\
\infty\end{array}$ & \begin{tabular}{l}
\multirow{f}{A}{} \\
6
\end{tabular} & $\left.\begin{array}{l}\hat{n} \\
\infty \\
\infty\end{array}\right]$ & $\begin{array}{l}\stackrel{0}{7} \\
\stackrel{m}{n}\end{array}$ & $\begin{array}{l}\vec{N} \\
\stackrel{2}{2}\end{array}$ & $\begin{array}{l}\stackrel{8}{0} \\
\infty \\
\sim\end{array}$ & $\begin{array}{l}\overrightarrow{0} \\
i \\
i n\end{array}$ & 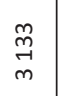 & $\begin{array}{l}\tilde{Z} \\
\sigma \\
\sigma\end{array}$ & $\begin{array}{l}\mathscr{g} \\
\dot{\sigma} \\
\sigma\end{array}$ & $\begin{array}{l}\vec{\sigma} \\
\vec{y}\end{array}$ & $\stackrel{\overrightarrow{0}}{n}$ & $\begin{array}{l}\mathbb{J} \\
0 \\
\sigma\end{array}$ & 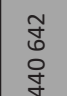 \\
\hline 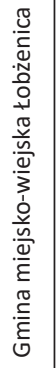 & 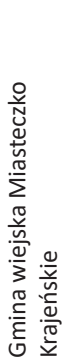 & 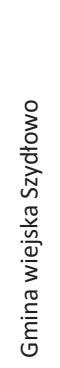 & 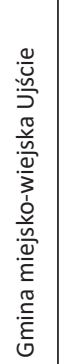 & 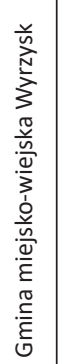 & 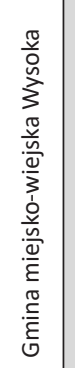 & 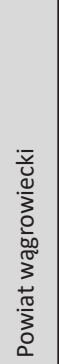 & 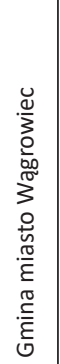 & 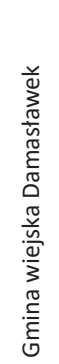 & 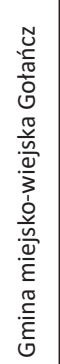 & 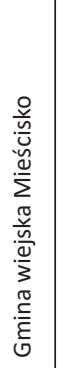 & 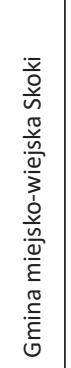 & 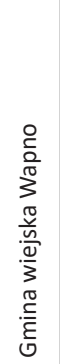 & 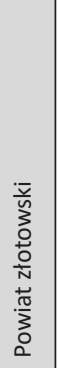 & 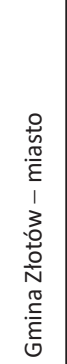 & 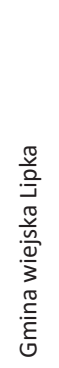 & 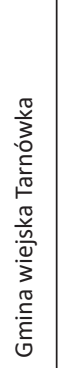 & 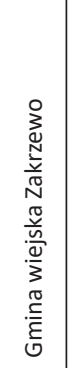 & 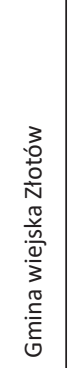 & 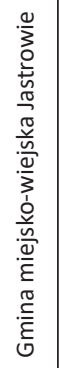 & 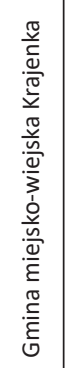 & 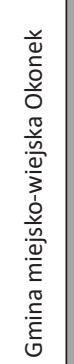 & 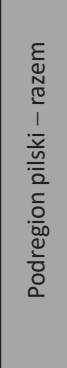 \\
\hline
\end{tabular}




\section{Wnioski badawcze}

Przedstawione w niniejszym artykule wyniki badań dotyczą tylko podstawowych kwestii związanych $z$ funkcjonowaniem oferty publicznego transportu zbiorowego, takich jak obecność oferty, liczba połączeń, system taryfowy i dostępność do informacji o połączeniach i taryfach. Pozwalają one jednak zwrócić uwagę na istotny wątek dla przyszłych badań nad dostępnością przestrzenną i nad rozwojem regionalnym. Powiat wągrowiecki, stanowiący część podregionu pilskiego, od września 2017 r. został objęty zasięgiem atrakcyjnego cenowo (bilet miesięczny z Wągrowca - 294 zł), zintegrowanego z komunikacją miejską w Poznaniu biletu okresowego „Bus Tramwaj Kolej". Następnie, w ramach przygotowań do wdrożenia Poznańskiej Kolei Metropolitalnej (por. Bul, 2016), jak i podczas uruchomienia PKM w czerwcu 2018 r., zwiększona została częstotliwość kursów. Jednocześnie podregion pilski cechuje się słabą spójnością transportową. Rodzi się więc pytanie, jak tworzenie atrakcyjnych ofert skierowanych do stolicy regionu będzie wpływało na rozwój peryferyjnych podregionów województwa i ich wewnętrzną spójność transportową? Czy będzie osłabiało subregionalne centra społeczno-ekonomiczne wzmacniając znaczenie Poznania?

\section{Wnioski praktyczne}

Na kanwie wyników badań przestrzennej dostępności transportu publicznego zidentyfikowano istotny problem, z którym muszą mierzyć się pasażerowie na obszarach pozamiejskich. Jest nim brak dostępu do kompleksowej i rzetelnej informacji o rozkładzie jazdy. Nie dotyczy to jedynie systemu kolei pasażerskiej, gdyż zarządca infrastruktury szlakowej zobowiązany jest do informowania za pośrednictwem witryny internetowej potencjalnych podróżnych o rozkładzie jazdy (art. 30e ustawa z dnia 28 marca 2003 r. o transporcie kolejowym; Dz.U. 2003 nr 86 poz. 789). Obowiązek ten realizowany jest poprzez „Portal Pasażera" (www.portalpasazera.pl), zawierający również informacje o połączeniach obsługiwanych na normalnotorowych szlakach będących w gestii innych zarządców (np. DSDiK, PKM). Przyjęta przez ustawodawcę formuła zapewnia neutralność informacji w stosunku do graczy rynkowych.

W przypadku transportu autobusowego nie istnieje żaden podmiot zobowiązany do udostępniania kompleksowej i aktualnej informacji pasażerskiej w sposób neutralny. Urzędy marszałkowskie zobligowane są do prowadzenia zestawień udzielonych zezwoleń na świadczenie usług. Rozkład jazdy jest integralną składową decyzji administracyjnej i stanowi istotną część warunków wykonywania regularnego przewozu osób. Zestawienia nie obejmują jednak czasowych odstępstw od warunków określonych w zezwoleniach, a informacja o zlikwidowanych kursach najczęściej aktualizowana jest po wielu miesiącach. Ponadto transport publiczny może odbywać się również na zasadzie wydawanych przez organizatorów (samorządy gminne, powiatowe, wojewódzkie lub ich związki) zaświadczeń potwierdzających uprawnienia do świadczenia usług. Sama informacja publikowana jest w sposób mało przyjazny, wymuszając na czytelniku konieczność zapoznania się z wieloma decyzjami administracyjnymi. W konsekwencji, kanały dystrybucji informacji pasażerskiej stają się elementem budowania przewagi konkurencyjnej przewoźników autobusowych.

Największym zasobem informacji, dostępnym dla pasażerów, jest strona internetowa prowadzona przez Polską Izbę Gospodarczą Transportu Samochodowego i Spedycji, której powstanie było możliwe dzięki środkom UE na rzecz wsparcia konkurencyjności polskich przedsiębiorstw. Strona Ogólnopolskiej Informacji o Połączeniach Autobusowych (www.autobusowyrozkladjazdy.pl) umożliwia wyszukiwanie połączeń, wyświetlanie tabliczek przystankowych oraz listy przewoźników i organizatorów publicznego transportu zbiorowego. Pojawiają się ponadto inicjatywy komercyjne, zarówno neutralne wobec podmiotów rynkowych (np. e-podroznik.pl spółki Teroplan), jak i platformy informacyjno-sprzedażowe prowadzone wspólnie przez kilku graczy rynkowych, mające na celu umocnienie pozycji rynkowej graczy (np. DworzecOnline.pl inicjatywa PKS Polonus).

W skali kraju ciekawy kierunek rozwoju informacji pasażerskiej wyznacza starostwo lublinieckie, prowadzące internetowy rozkład jazdy zawierający informację o wszystkich przewoźnikach przynajmniej raz zatrzymujących się na terenie powiatu (www. transportpowiat.pl), nawet gdy są to połączenia dalekobieżne czy międzynarodowe (np. FlixBus).

\section{Podsumowanie}

Przeprowadzone badania pokazały, iż istnieje duży problem z dostępnością transportu publicznego w podregionie pilskim. Wynika on przede wszystkim z nieatrakcyjnej oferty autobusowej, nastawionej na obsługę dowozu uczniów do szkół. Poza okresem zajęć szkolnych większość kursów nie odbywa się, przez co transport autobusowy nie jest atrakcyjny dla osób dojeżdżających regularnie do pracy. Brak spójnego systemu informacyjnego utrudnia z kolei wyszukiwanie połączeń przez osoby sporadycznie korzystające $z$ transportu publicznego. Skazuje to, zwłaszcza komunikację autobusową, na przegraną 
w konkurencji z indywidualną motoryzacją, pogłębiając wykluczenie transportowe. Oferta kolei regionalnych na tle transportu autobusowego jawi się jako stabilna i atrakcyjna cenowo. Jednak poprzez zawieszenia ruchu oraz fizyczne likwidacje torów ogranicza się tylko do głównych szlaków.

\section{Piśmiennictwo}

Banister D., 2001, Transport Planning, [w:] K. Button, D. Hensher (red.), Handbook of Transport Systems and Traffic Control, 3, Emerald Group Publishing Limited, 9-19.

Beim M., 2014, Wpływ dostępności transportem publicznym na rozwój społeczno-ekonomiczny województwa wielkopolskiego, Wielkopolskie Regionalne Obserwatorium Terytorialne, Urząd Marszałkowski Województwa Wielkopolskiego, Poznań.

Bul R., 2016, Droga do Poznańskiej Kolei Metropolitalnej działania na rzecz budowy systemu kolei w aglomeracji poznańskiej, Transport Miejski i Regionalny, 11, 23-29.

Bul R., Resiński T., 2014, Wpływ funduszy europejskich na funkcjonowanie i rozwój kolei regionalnych w centralnej części województwa wielkopolskiego w latach 2006-2014, Transport Miejski i Regionalny, 6, brak zakresu stron.

Drewnowski A., Małachowski K., 2015, Wpływ rewitalizacji przewozów na linii kolejowej Ulikowo-Kalisz Pomorski-Wałcz (Piła Gł.) na wzrost konkurencyjności regionu i mobilności jego mieszkańców, Zeszyty Naukowe. Problemy Transportu i Logistyki, Uniwersytet Szczeciński, 30, 25-36.

Gadziński J., Beim M., 2009, Dostępność przestrzenna lokalnego transportu publicznego w Poznaniu, Transport Miejski i Regionalny, 5, 10-16.

Gadziński J., 2013, Funkcjonowanie lokalnego systemu transportowego na tle współczesnych procesów urbanizacyjnych. Przykład aglomeracji poznańskiej, Bogucki Wydawnictwo Naukowe, Poznań.

Gibbons S., Heblich S., Pinchbeck T., 2018, The spatial impacts of a massive rail disinvestment program: the Beeching Axe. Discussion Paper No 1563, London School of Economics and Political Science, Londyn.

Goliszek S., Połom M., 2016, Porównanie dostępności komunikacyjnej transportem zbiorowym w ośrodkach wo- jewódzkich Polski Wschodniej na koniec perspektywy UE 2007-2013, Transport Miejski i Regionalny, 3, 16-26.

Malasek J., 2017, Metoda oceny dostępności i atrakcyjności przystanków miejskiego transportu zbiorowego, Transport Miejski i Regionalny, 9, 26-32.

Moseley M.J., 1979, Accessibility: the rural challenge, Methuen and Company Limited, Londyn.

Otsuka N., Delmastro T., Wittowsky D., Pensa S., Damerau M., 2019, Assessing the accessibility of urban nodes: the case of TEN-T railway stations in Europe, Applied Mobilities, 4, (2), 219-243.

Preston J., Rajé F., 2007, Accessibility, mobility and transport-related social exclusion, Journal of Transport Geography, 15 (3), 151-160.

Rosik P., Pomianowski W., Kołoś A., Guzik R., Goliszek S., Stępniak M, Komornicki T., 2018, Dostępność gmin transportem autobusowym, Prace Komisji Geografii Komunikacji PTG, 21 (1), 54-64.

Sior E., 2013, Ocena jakości dojścia pasażerów do pociągów na wybranych stacjach kolejowych, Praca magisterska pod kierunkiem J. Rychlewskiego, Wydział Budownictwa i Inżynierii Środowiska Politechniki Poznańskiej.

Soczówka A., 2012, Zróżnicowanie struktury przestrzennej komunikacji miejskiej w konurbacji katowickiej, Prace Wydziału Nauk o Ziemi Uniwersytetu Śląskiego, Wydział Nauk o Ziemi Uniwersytetu Śląskiego, Sosnowiec.

Sołtysiak J., 2014, Ocena jakości obsługi pasażerów na wybranych stacjach i przystankach kolejowych aglomeracji poznańskiej, Praca magisterska pod kierunkiem J. Rychlewskiego, Wydział Budownictwa i Inżynierii Środowiska Politechniki Poznańskiej.

Stanny M., Rosner A., Komorowski Ł., 2018, Monitoring rozwoju obszarów wiejskich. Etap III. Struktury społeczno-gospodarcze, ich przestrzenne zróżnicowanie i dynamika, EFRWP, IRWiR PAN, Warszawa.

Taylor Z., 1999, Przestrzenna dostępność miejsc zatrudnienia, kształcenia i usług a codzienna ruchliwość ludności wiejskiej, Prace Geograficzne, 171, IGiPZ PAN, Warszawa.

Wolański M., Paprocki W., Mazur B., Soczówka A., Jakubowski B., Czubak M., Pieróg M., 2016, Publiczny transport zbiorowy poza miejskimi obszarami funkcjonalnymi: diagnoza, analiza zróżnicowania, oddziaływania społeczne, rekomendacje, Oficyna Wydawnicza - Szkoła Główna Handlowa, Warszawa. 